\title{
Whole-rock and zircon evidence for evolution of the Late Jurassic high Sr/Y Zhoujiapuzi granite, Liaodong Peninsula, North China Craton
}

${ }^{1}$ State Key Laboratory of Nuclear Resources and Environment, East China University of Technology, Nanchang, 330013, Jiangxi, China;

${ }^{2}$ School of Earth Sciences, East China University of Technology, Nanchang, 330013, China,

${ }^{3}$ Department of Earth Sciences, Durham University, Durham DH1 3LE, UK

$10{ }^{4}$ School of Geosciences and Info-Physics, Central South University, Changsha 410083, China

Correspondence to: Renyu Zeng (zengrenyu@126.com)

Abstract. Middle-Late Jurassic high Sr/Y granitic intrusions are extensively exposed in the Liaodong Peninsula, in the eastern part of the North China Craton (NCC). However, the genesis of the high Sr/Y signature in these intrusions has not been studied in detail. In this study, we report results of zircon U-Pb dating, Hf isotopic analysis and zircon and whole-rock

15 geochemical data for the Late Jurassic Zhoujiapuzi granite in the middle part of the Liaodong Peninsula. The Zhoujiapuzi granite is high-K (calc-alkaline) and peraluminous in nature, with high $\mathrm{SiO}_{2}\left(68.1-73.0\right.$ wt \%) and $\mathrm{Al}_{2} \mathrm{O}_{3}(14.5-16.8$ wt \%), low in $\mathrm{TFe}_{2} \mathrm{O}_{3}\left(1.10-2.49\right.$ wt \%) and $\mathrm{MgO}\left(0.10-0.44\right.$ wt \%), and with high $\mathrm{Sr} / \mathrm{Y}(19.9-102.0)$ and $\mathrm{La}_{\mathrm{N}} / \mathrm{Yb}_{\mathrm{N}}(14.59-80.40)$. Morphological and chemical studies on zircon grains show that there are two stages of zircon growth, interpreted as magmatic evolution in two distinct stages. The early stage of zircons (ESZ) reflects a crystallization environment of low oxygen fugacity and high $\mathrm{T}_{\mathrm{Zr}-\mathrm{Ti}}$ (Ti-in-zircon thermometer values: $669-792^{\circ} \mathrm{C}$ ); the late stage of zircons (LSZ) formed with high oxygen fugacity and lower $\mathrm{T}_{\mathrm{Zr}-\mathrm{Ti}}\left(498-720^{\circ} \mathrm{C}\right)$. LA-ICP-MS U-Pb zircon dating yielded the formation ages of the ESZ and LSZ of $\sim 162 \pm 1 \mathrm{Ma}$ and $\sim 158 \pm 1 \mathrm{Ma}$, respectively, with similar $\varepsilon \mathrm{Hf}(\mathrm{t})$ values in the range of -26.3- -22.8. Interpretation of the elemental and isotopic data suggests that the Zhoujiapuzi granite was a I-type granite derived from partial melting of basement in the region: $\sim 2.17 \mathrm{Ga}$ Liaoji granites. The high $\mathrm{Sr} / \mathrm{Y}$ signature is most likely inherited from these source rocks.

25 Based on the geochemical features and regional geological data, we propose that the Liaodong Peninsula in the Late Jurassic was part of a mature continental arc, with extensive melting of thick crust above the Paleo-Pacific subduction zone.

\section{Introduction}

The Liaodong Peninsula is located in the northeast of the North China Craton (NCC). The northeast NCC was influenced by three main tectonic regimes in the Mesozoic, related to the subduction of the Paleo-Asian, Paleo-Pacific and MongolOkhotsk oceans (Tang et al., 2018). The superposition of these different regimes resulted in changing tectonic and magmatic patterns over time.

Middle-Late Jurassic granitic rocks are extensively exposed in the northern parts of the Liaodong Peninsula, such as the 
https://doi.org/10.5194/se-2021-129

Preprint. Discussion started: 17 November 2021

(c) Author(s) 2021. CC BY 4.0 License.

\section{(c) (1)}

Yutun diorite, Xiaoheishan granodiorite, Heigou monzogranite (Wu et al., 2005), Wulong two-mica Monzogranite (Yang et al., 2018), and Huangdi biotite monzogranite (Xue et al., 2020). Most of these rocks are characterized by high Sr/Y, and plot within the adakite field on $\mathrm{Sr} / \mathrm{Y}-\mathrm{Y}$ and $\mathrm{La}_{\mathrm{N}} / \mathrm{Yb}_{\mathrm{N}}-\mathrm{Yb}_{\mathrm{N}}$ diagrams (Wu et al., 2005a; Yang et al., 2015a, 2018). Adakite and geochemically similar high $\mathrm{Sr} / \mathrm{Y}$ igneous rocks have been proposed to represent several tectonic environments (Defant and Drummond, 1990; Castillo et al., 1999; Gao et al., 2004; Kamei et al., 2009; Ma et al., 2013; Ma et al., 2015; Ou et al., 2017; Yang et al., 2020). The Middle-Late Jurassic granitic rocks in the Liaodong Peninsula are commonly proposed to be the products of partial melting of thickened mafic crust with garnet in the residue (Wu et al., 2005a; Yang et al., 2015a, 2018;

40 Tang et al., 2018).

In recent years, some studies have proposed that the high $\mathrm{Sr} / \mathrm{Y}$ ratio in granitic rocks can be inherited from a high $\mathrm{Sr} / \mathrm{Y}$ source (Kamei et al., 2009; Ma et al., 2015; Zhan et al., 2020). However, the source composition has not been fully considered in the petrogenesis of the high Sr/Y rocks in the Liaodong Peninsula. Hence, the petrogenesis of the Middle-Late Jurassic high $\mathrm{Sr} / \mathrm{Y}$ rocks needs to be reevaluated, based on more detailed work and a consideration of possible sources. This petrogenesis is of significance for understanding the Jurassic tectonics of the Liaodong Peninsula, and the NCC in general.

In this paper, we examined the high $\mathrm{Sr} / Y$ Zhoujiapuzi granite from the Xiuyan area, in the middle of the Liaodong Peninsula. Zircons are analysed for U-Pb-Hf isotopes and trace element geochemistry, and by Raman spectroscopy. These results are integrated with whole-rock geochemistry. We focus on the zircons, because of their potential to reveal the origins of the pluton (Belousova et al., 2002; Wang et al., 2007; Breiter et al., 2014; Zhao et al., 2014), and so provide a case study

50 for the evolution of plutonic magma systems in general. Based on observations of the CL images and chemical analysis, two zircon growth stages can be distinguished. We first determine the crystallization environments of the two zircon growth stages, and then decipher the petrogenesis, source characteristics and origin of the high $\mathrm{Sr} / \mathrm{Y}$ signature of the pluton as a whole. Integrated with previous studies, our study provides insights into the tectonic evolution of the Liaodong Peninsula in the Late Jurassic.

\section{Geological setting}

The Zhoujiapuzi granite is located in the middle of the Liaodong Peninsula, at the northeastern margin of the NCC (Fig. 1). The Paleoproterozoic Liaohe Group is the basement in the study area, including the Lieryu, Gaojiayu, Dashiqiao and Gaixian formations. Although stratigraphic terms are used, these rocks are metamorphic, and the group consists of leptynite, leptite, granulite, amphibolite, marble and phyllite. The protoliths of the Liaohe Group include marine volcanics, clastics, carbonates and claystones. The formation age of the metasedimentary rocks in the Liaohe Group is 2.0-1.9 Ga (Wan et al., 2006; Li et al., 2015). It is in unconformable contact with the overlying strata of the Mesoproterozoic Cuocaogou Formation and Xiaoling Formation.

In the Mesozoic, the region of the Liaodong Peninsula was influenced by the circum-Pacific tectonic regime, the Mongol-Okhotsk tectonic regime and the Paleo-Asian Ocean tectonic regime. The joint influence of multiple tectonic 
https://doi.org/10.5194/se-2021-129

Preprint. Discussion started: 17 November 2021

(c) Author(s) 2021. CC BY 4.0 License.

(c) (i)

65 regimes resulted in intensive magmatism during the Mesozoic (Fig. 1b). These Mesozoic magmatic rocks can be divided into three stages, namely: Triassic (233-212 Ma), Jurassic (180-156 Ma) and Early Cretaceous (131-117 Ma) (Wu et al., 2005b).

The Triassic magmatic rocks are less exposed, mainly alkaline rocks, diabase, diorites and granites (Wu et al., 2005b). Among them, the granites mainly have A-type affinity, and may have formed in an extensional setting (Tang et al., 2018; Wang et al., 2019). Magmatism has been related to either the subduction of the Paleo-Pacific slab, closure of the Paleo-Asian

70 Ocean, or the collision between the NCC and the Yangtze Craton (Tang et al., 2018; Wang et al., 2019). The majority of the Jurassic magmatic rocks are monzogranite, tonalite and granodiorite, which are generally calc-alkaline I-type granites, and show characteristics of adakite-like rocks. Some of them, exposed near later extensional structures, have undergone regional ductile deformation. These Jurassic magmatic rocks are generally considered to relate to the subduction of the Paleo-Pacific slab (Li et al., 2004; Zhai et al., 2004). In the Early Cretaceous, basic-acidic-alkaline rocks were widely developed. Among

75 them, the granites have mainly A- and I-type affinities. These rocks are generally considered to have formed in an intense extension environment, which is connected with either the rollback or low-angle subduction of the Paleo-Pacific slab (Wu et al., 2005c; Zheng et al., 2018).

\section{Samples and petrography}

The Zhoujiapuzi granite is located to the east of Xiuyan City, in the middle of the Liaodong Peninsula (Fig. 1b). It intruded

80 into the Lieryu Formation of the Liaohe Group. Eight samples of the Zhoujiapuzi granite were collected at locations shown in Fig. 1c.

The Zhoujiapuzi granite is generally grey in colour and with fine-grained texture (Fig. 2a). The mineral assemblage contains K-feldspar ( $\sim 50 \%)$, quartz ( $25 \%)$, plagioclase $(\sim 20 \%)$ and biotite $(\sim 5 \%)$ as well as accessory minerals such as zircon, ilmenite, magnetite and apatite. K-feldspar are euhedral or subhedral, always exhibit cross-hatched twinning (Fig. 2b).

85 Quartz is usually xenomorphic, and have indented boundaries and wavy extinction (Fig. 2b-d). Plagioclase always exhibits polysynthetic twinning and have sericitization in places (Fig. 2c). Biotite mainly fills in the interstices between the other minerals (Fig. 2c, d).

\section{Analytical methods}

The cathodoluminescence (CL) images of zircon were obtained by the Chengpu geological Testing Co. Ltd, Langfang, China

90 using the TIMA analysis. The LA-ICP-MS zircon U-Pb analyses were performedusing an Agilent Technologies 7700x ICPMS with a Teledyne Cetac Technologies Analyte Excite laser-ablation system at Nanjing FocuMS Contract Testing Co. Ltd. The analyses were carried out with a $35 \mu \mathrm{m}$ spot size at $8 \mathrm{~Hz}$ repetition rate for 40 seconds. The raw ICP-MS data were processed using ICPMSDataCal software (Liu et al., 2010). Date reduction were completed using the Isoplot4.15 (Ludwig, 2003). The instrument description and analytical procedure are described in detail by Zeng et al. (2018). 
https://doi.org/10.5194/se-2021-129

Preprint. Discussion started: 17 November 2021

(c) Author(s) 2021. CC BY 4.0 License.

\section{(c) (1)}

The in-situ Lu-Hf isotopic analyses of zircon were performed by LA-MC-ICP-MS using a Teledyne Cetac laserablation system and a Nu Plasma II MC-ICP-MS at Nanjing FocuMS Contract Testing Co. Ltd. The $193 \mathrm{~nm}$ ArF excimer laser was focused on zircon surface with fluence of $6.0 \mathrm{~J} / \mathrm{cm}^{2}$. The ablation protocol employed a spot diameter of 50 um at 8 $\mathrm{Hz}$ repetition rate for 40 seconds. A more detailed description of the method was described by Zeng et al. (2018).

Zircon Raman analyses were carried out using an RM2000 laser Raman spectrometer at the State Key Laboratory of

100 Nuclear Resources and Environment, East China University of Technology. The selected incident wavelengths were 532 and $785 \mathrm{~nm}$ in order to clearly identify the luminescence bands due to low concentration impurities. The beam power was 20 $\mathrm{mW}$. The Leica $50 \times$ objective was employed.

Six fresh rock samples were selected for geochemical analysis. The elemental analyses were conducted at Analytical Chemistry \& Testing Services (ALS) Chemex (Guangzhou) Ltd. Major oxides were analyzed using wave-dispersive X-ray fluorescence (XRF) (ME-XRF26). Analytical precision was better than $\pm 0.01 \%$. Trace element abundances were measured by the lithium borate dissolution method and ICP-MS (ME-MS81). The analytical uncertainties of the rare earth element (REE) and high field strength element (HFSE) are $<5 \%$. Analytical uncertainties are in the range of $5 \%-10 \%$ for the other elements. Detailed analytical procedures refer to Zhang et al. (2019) and Nash et al. (2020).

\section{Analytical results}

110 The data for major and trace elements, Raman microprobe data, zircon trace elements, zircon U-Pb ages, and zircon $\mathrm{Hf}$ isotopes are shown in Tables S1, S2, S3, S4 and S5, respectively.

\subsection{Whole-rock major and trace element compositions}

$\mathrm{SiO}_{2}$ contents ranging from 68.11 wt.\% to 73.02 wt.\% (average 71.71 wt.\%). Contents of $\mathrm{Na}_{2} \mathrm{O}$ and $\mathrm{K}_{2} \mathrm{O}$ are $3.81-4.65$ wt.\% and 4.32-4.71 wt.\%, respectively, with $\mathrm{Na}_{2} \mathrm{O} / \mathrm{K}_{2} \mathrm{O}$ ratio of $0.82-1.08$ and total alkalis $\left(\mathrm{Na}_{2} \mathrm{O}+\mathrm{K}_{2} \mathrm{O}\right)$ of 8.38-8.97. All

115 samples plot in the field of granite in the TAS classification except one (Fig. 3a). These samples have $\mathrm{Al}_{2} \mathrm{O}_{3}$ contents of 14.49-16.83 wt.\% (average 15.09 wt.\%), CaO contents of 1.04-1.98 wt.\% (average 1.38 wt.\%) and A/CNK values of 1.051.10 (average 1.07). In the A/NK-A/CNK diagram (Fig. 3b), all samples plot in the peraluminous field (Fig. 3b). The granite samples have low $\mathrm{TFe}_{2} \mathrm{O}_{3}\left(\mathrm{TFe}_{2} \mathrm{O}_{3}=\right.$ all Fe calculated as $\left.\mathrm{Fe}_{2} \mathrm{O}_{3}\right)$ contents and $\mathrm{MgO}$ contents ranging from 1.10-2.49 wt \% and $0.10-0.44 \mathrm{wt} \%$, respectively, with $\mathrm{Mg} \#(\mathrm{Mg} \#=100 *$ molar $\mathrm{Mg} /(\mathrm{Mg}+\mathrm{Fe}))$ values of $15-26$.

The samples of the Zhoujiapuzi granite exhibit variable REEs, with total REEs ranging from 59 to $302 \mathrm{ppm}$. The $\mathrm{La}_{\mathrm{N}} / \mathrm{Yb}_{\mathrm{N}}$ values of the Zhoujiapuzi granite range from 14.59 to 80.40 (average 38.27), showing right-declined REE patterns (Fig. 4a). The samples have Eu/Eu* of $0.62-1.94$ and $\mathrm{Ce} / \mathrm{Ce} *$ of $0.94-1.16$. In the primitive mantle-normalized trace element diagram (Fig. 4b), the samples show negative anomalies of HFSEs (e.g., Nb, Ta, Ti and P) and positive anomalies of La and LILEs (e.g., K, Rb, Ba, U, La, Ce). The Zhoujiapuzi granite is characterized by high contents of Sr (309-551 ppm) and low contents of $\mathrm{Y}(5.01-15.5 \mathrm{ppm})$ and $\mathrm{Yb}(0.43-1.40 \mathrm{ppm})$, with high $\mathrm{Sr} / \mathrm{Y}$ ratios of 19.94-102.04 (average 65.50). 
https://doi.org/10.5194/se-2021-129

Preprint. Discussion started: 17 November 2021

(c) Author(s) 2021. CC BY 4.0 License.

\section{(c) (i)}

\subsection{Zircon CL images, Raman spectra and REE elements}

CL images of zircons from the Zhoujiapuzi granite are shown in Fig. 5. Zircons commonly have crystal sizes between 120 and $200 \mu \mathrm{m}$, and have length/width ratios of 2:1-4:1, with euhedral, stubby to elongate prisms. According to the CL images, there were two stages for zircon growth, and the zircons can be divided individually and collectively into: the early stage of zircon (ESZ) and the late stage of zircon (LSZ). The ESZ is characterized by bright CL intensity and widely-spaced oscillatory zoning patterns. The LSZ is characterized by extremely low CL emission and narrowly-spaced oscillatory zoning patterns.

Six ESZ spots and six LSZ spots were analyzed for Raman spectra. The ESZ have antisymmetric stretching vibration $\left(\mathrm{B}_{1 \mathrm{~g}}\right)$ of the $\mathrm{SiO}_{4}$ tetrahedra $\left(v_{3}\left(\mathrm{SiO}_{4}\right)\right)$ Raman band of $1005-1007 \mathrm{~cm}^{-1}$ and half-width of the $v_{3}\left(\mathrm{SiO}_{4}\right)$ Raman band $(b)$ values of $6.0-8.1 \mathrm{~cm}^{-1}$, while the LSZ have $v_{3}\left(\mathrm{SiO}_{4}\right)$ Raman band of $1004-1007 \mathrm{~cm}^{-1}$ and $b$ values of $5.4-9.0 \mathrm{~cm}^{-1}$.

Twenty ESZ spots and eighteen LSZ spots were analyzed for trace and rare earth elements. The ESZ spots have lower U content (28-677 ppm) than that of the LSZ spots (U=641-3842 ppm). In the chondrite-normalized REE element diagram (Fig. 6a, b), both the ESZ and LSZ characterized by HREE enrichment relative to LREE with positive Ce anomalies and negative Eu anomalies. The ESZ spots have $\Sigma$ REE of 49-1115 ppm (average 390 ppm), $\Sigma$ LREE of 3-72 ppm (average 14 ppm) and $\Sigma$ HREE of 46-1100 ppm (average 377 ppm), whereas the LSZ spots have $\Sigma$ REE of 327-1632 ppm (average 895 ppm), LLREE of 2-14 ppm (average $6 \mathrm{ppm}$ ) and LHREE of 325-1627 ppm (average $889 \mathrm{ppm}$ ). Hence, the REE content of the ESZ is significantly lower than that of the LSZ, and the difference between the two is mainly in HREE content. The ESZ spots have $\delta \mathrm{Eu}$ of $0.07-0.60$ (average 0.28 ) and $\delta \mathrm{Ce}$ of $1.26-166.54$ (average 45.49). The LSZ spots have $\delta \mathrm{Eu}$ of $0.08-0.24$ (average 0.13) and $\delta \mathrm{Ce}$ of 4.23-271.90 (average 94.37). These results indicate that the ESZ have a weaker negative Eu

145 anomaly and a weaker positive Ce anomaly than those of the LSZ.

Some zircons have inherited cores, which have corroded and rounded shapes, such as the 1\# in XY-001 and 6\# and 41\# in XY-008 (Fig. 5). These inherited zircons have oscillatory zoning in CL images. The inherited zircon spots have $\Sigma$ REE of 602-1517 ppm, and show depletion of LREE, enrichment of HREE, a positive Ce anomaly ( $\delta \mathrm{Ce}$ of $1.52-216.08$ ) and a negative Eu anomaly ( $\delta \mathrm{Eu}$ of $0.07-0.13$ ) (Fig. 6c).

\subsection{Zircon $\mathrm{U}-\mathrm{Pb}$ and $\mathrm{Hf}$ isotope composition}

Seventy-seven spots were analysed for U-Pb isotope composition from samples XY-001 and XY-008. In the U-Pb Concordia diagram (Fig. 7a, d), both the ESZ and LSZ spots are clustered on the Concordia curve. Overall, the ages of LSZ are generally older than those of ESZ (Fig. 8). On a single zircon, the ${ }^{206} \mathrm{~Pb} /{ }^{238} \mathrm{U}$ age of the ESZ is older than that of the LSZ (Fig. 5). In sample XY-001, 13 spots from ESZ define a weighted mean ${ }^{206} \mathrm{~Pb} /{ }^{238} \mathrm{U}$ age of $160.8 \pm 1.3 \mathrm{Ma}(1 \sigma$, MSWD=0.62; Fig.

$1557 \mathrm{~b})$, and 19 spots from LSZ define a weighted mean ${ }^{206} \mathrm{~Pb} /{ }^{238} \mathrm{U}$ age of $157.8 \pm 0.8 \mathrm{Ma}(1 \sigma, \mathrm{MSWD}=0.42$; Fig. 7c). In sample $\mathrm{XY}-008,19$ spots from ESZ define a weighted mean ${ }^{206} \mathrm{~Pb} /{ }^{238} \mathrm{U}$ age of $161.5 \pm 1.1 \mathrm{Ma}(1 \sigma, \mathrm{MSWD}=0.32$; Fig. $7 \mathrm{e})$, and 16 spots from LSZ define a weighted mean ${ }^{206} \mathrm{~Pb} /{ }^{238} \mathrm{U}$ age of $157.8 \pm 0.9 \mathrm{Ma}(1 \sigma, \mathrm{MSWD}=0.39$; Fig. $7 \mathrm{f})$. The other 10 spots with 
https://doi.org/10.5194/se-2021-129

Preprint. Discussion started: 17 November 2021

(c) Author(s) 2021. CC BY 4.0 License.

\section{(c) (1)}

distinctly older ages $\left({ }^{207} \mathrm{~Pb} /{ }^{206} \mathrm{~Pb}\right.$ ages ranging from 2494 to $\left.2132 \mathrm{Ma}\right)$ were obtained on inherited cores. Their ages are discordant, suggesting that these inherited cores were variably influenced by lead loss. Among these, 9 spots define a discordia line with an upper intercept age of $2167 \pm 12 \mathrm{Ma}(\mathrm{MSWD}=0.59)$ (Fig. $7 \mathrm{~g}$ ), which is concordant with the weighted mean ${ }^{207} \mathrm{~Pb} /{ }^{206} \mathrm{~Pb}$ ages of $2167 \pm 12 \mathrm{Ma}(1 \sigma, \mathrm{MSWD}=0.54$; Fig. $7 \mathrm{~h})$.

Twenty-four zircons were analyzed for $\mathrm{Lu}-\mathrm{Hf}$ isotope composition. The variation in $\mathrm{Hf}$ isotopic data is limited, between 9 spots from ESZ and 8 spots from LSZ. 17 spots exhibit a range of ${ }^{176} \mathrm{Hf} /{ }^{177} \mathrm{Hf}$ ratios from 0.281921 to 0.282030 , which converts to $\varepsilon \mathrm{Hf}(\mathrm{t})$ values between -26.3 to -22.8 (Fig. 9), and two-stage Hf model (T⿰M2) ages of 2650 to 2889 Ma by using the U-Pb age for each zircon. Six analytical spots, which define the Concordia upper intercept age of $2167 \mathrm{Ma}$, show ${ }^{176} \mathrm{Hf} /{ }^{177} \mathrm{Hf}$ radios and $\varepsilon \mathrm{Hf}(\mathrm{t})$ values of 0.281443 to 0.281496 and -0.7 to 1.2 , respectively, with $\mathrm{T}_{\mathrm{DM} 2}$ age of $2646 \mathrm{Ma}$ to 2788 Ma by using the upper intercept age.

\section{Discussion}

\subsection{Significance of the two stages of zircon}

170 Generally, zircon with high $U$ content can easily break down into the metamict state because of the radiation damage to the lattice caused by $\alpha$-particles originating from the decay of uranium (Mezger and Krogstad, 1997). The physical and structural changes often lead to the loss of $\mathrm{Pb}$ and addition of trace elements such as LREE. In this study, the LSZ are characterized by high U content. Hence, the metamictization degree of the zircons must be taken into consideration. Data from LSZ spots plot on the Concordia curve, indicating no obvious Pb loss. The internal structure of LSZ is relatively intact, with obvious oscillatory zoning, and few cracks, implying that the physical and structural of the LSZ remained unchanged. Nasdala et al. (1998) suggested that the metamictization of zircon can be well characterized by Raman spectroscopy. The half-width of the $v_{3}\left(\mathrm{SiO}_{4}\right)$ Raman band $(b)$ of $10 \mathrm{~cm}^{-1}$ and $20 \mathrm{~cm}^{-1}$ are proposed to approximately distinguish well-crystallized, intermediate and metamict zircons (Nasdala et al., 1998). The LSZ have $b$ values of 5.4-9.2, characterizing them as well-crystallized. Therefore, the above features indicate that the LSZ are not metamict. Consequently, it can be concluded that the U-Pb isotope and trace element systematics of the LSZ have not been changed by metamictization.

Both the ESZ and LSZ have oscillatory zoning patterns, and their chondrite-normalized REE patterns are characterized by steeply positive slopes from the LREE to HREE with strong negative Eu anomalies and pronounced positive Ce anomalies. The above characteristics are consistent with those of igneous zircon (Hoskin and Schaltegger, 2003). Although hydrothermal zircon can also have oscillatory zoning patterns similar to magmatic zircons, there are obvious differences in trace elements between the magmatic and hydrothermal zircon (Hoskin et al., 2005). In the discrimination diagram (Fig. 10), both the spots of ESZ and LSZ fall in or near the magmatic field, which is obviously different from hydrothermal zircon. Hence, the above characteristics indicate that both the ESZ and LSZ from the Zhoujiapuzi granite have a magmatic origin.

The ESZ was overgrown continuously by the LSZ. In addition, the contact between the ESZ and LSZ is euhedral. Such core-mantle overgrowth relationships indicate that both the ESZ and LSZ formed in two stages of the same magmatism (i.e. 
https://doi.org/10.5194/se-2021-129

Preprint. Discussion started: 17 November 2021

(c) Author(s) 2021. CC BY 4.0 License.

the ESZ are not xenocrysts or inherited zircons). Furthermore, the similar Hf isotopic data of the ESZ and LSZ is also consistent with this interpretation. The obvious difference in internal structure and trace element composition between the ESZ and LSZ could be due to significant and abrupt changes in their crystallization environments (Wang et al., 2007).

Watson and Harrison (2005) found that the Ti content of zircon has a strong dependence on temperature (T), and obtain a Ti-in-zircon thermometer ( $\left.\mathrm{T}_{\mathrm{Zr}-\mathrm{Ti}}\right)$. Since then, Ferry and Watson (2007) suggested that the solubility of Ti in zircon depends not only on $\mathrm{T}$ and activity of $\mathrm{TiO}_{2}\left(\mathrm{aTiO}_{2}\right)$ but also on the activity of $\mathrm{SiO}_{2}\left(\mathrm{aSiO}_{2}\right)$, and revised the $\mathrm{Tzr}$-Ti. We use the Tzr-Ti from Ferry and Watson (2007) and the recommended values $\left(\mathrm{aSiO}_{2}=1, \mathrm{aTiO}_{2}=0.6\right)$ for the activity of $\mathrm{SiO}_{2}$ and $\mathrm{TiO}_{2}$, due to the presence of ilmenite and quartz and lack of sphene and rutile in the Zhoujiapuzi granite. The Tzr-Ti from the ESZ and LSZ are $669-792{ }^{\circ} \mathrm{C}$ (average $734^{\circ} \mathrm{C}$ ) and $498-720^{\circ} \mathrm{C}$ (average $621^{\circ} \mathrm{C}$ ), respectively, i.e. the ESZ formed at higher temperatures than the LSZ. The U content shows a significant negative correlation with T (Fig. 11a).

Cerium exists in magmas as both $\mathrm{Ce}^{3+}$ and $\mathrm{Ce}^{4+}$. Because the $0.84-\AA \AA$ radius of the $\mathrm{Zr}^{4+}$ ion is more closely matched by the $\mathrm{Ce}^{4+}(0.97-\AA$ radius $)$ than the $\mathrm{Ce}^{3+}(1.143-\AA$ radius $)$ (all ionic radii are from Shannon, 1976), $\mathrm{Ce}^{4+}$ is more compatible in the zircon structure than the $\mathrm{Ce}^{3+}$. Hence, zircon $\mathrm{Ce}^{4+} / \mathrm{Ce}^{3+}$ ratio is a useful tool for evaluating the oxygen fugacity condition of crystallization environment (Ballard et al., 2002). In this study, the $\mathrm{Ce}^{4+} / \mathrm{Ce}^{3+}$ ratio of the ESZ and LSZ are 6.30-153.36 (average 32.51) and 21.81-5773.06 (average 787.39), respectively (the calculation method after Ballard et al., 2002). As shown in the $\mathrm{Ce}^{4+} / \mathrm{Ce}^{3+}-\mathrm{U}$ diagram (Fig. 11b), $\mathrm{U}$ has a significant positive correlation with $\mathrm{Ce}^{4+} / \mathrm{Ce}^{3+}$. This result implies that the LSZ formed in a higher oxygen fugacity environment than the ESZ.

$\mathrm{The} \mathrm{Zr} / \mathrm{Hf}$ ratio in zircon has a negative correlation with the degree of fractionation in the parent melt (Breiter et al., 2014). The Zr/Hf ratios of the ESZ (39-56) are obviously higher than those of the LSZ (21-40) (Fig. 11c). Hence, the above features reflect that the LSZ crystallized from a later and more evolved magma. The lowest $\mathrm{Zr} / \mathrm{Hf}$ value of the LSZ is less than 25, which indicates that the Zhoujiapuzi granite finally evolved into a highly fractionated granite due to crystallization differentiation. It is consistent that all the samples of the Zhoujiapuzi granite are characterized by relatively high $\mathrm{SiO}_{2}$ and total alkali contents, low $\mathrm{TFe}_{2} \mathrm{O}_{3}, \mathrm{MgO}$ and $\mathrm{CaO}$ contents, and enrichment of $\mathrm{Rb}$, Th and $\mathrm{U}$ (Xiao et al., 2014).

The absence of enclaves and disequilibrium textures in the Zhoujiapuzi granite and uniform $\varepsilon \mathrm{Hf}(\mathrm{t})$ values of the ESZ and LSZ do not support magma mixing and wall-rock assimilation. Consequently, the abrupt change between the crystallization environment of the ESZ and LSZ is not due to the magma mixing or contamination during magma evolution. Therefore, we propose that the ESZ was formed in a relatively deep magma chamber, which had low oxygen fugacity, low $\mathrm{Zr}$ saturation and high temperature. The low Th, $\mathrm{U}$ and REE, and widely-spaced oscillatory zoning patterns indicate a low growth rate of zircon (Hoskin and Schaltegger, 2003; Wang et al., 2011). In contrast, the LSZ was formed during the ascent and/or at the emplacement location of the magma. At this stage, the oxygen fugacity significantly increased, the temperature decreased, and $\mathrm{Zr}$ saturation increased due to the crystallization differentiation. In this environment, the crystallization rate of zircon significantly increased, forming the zircons with a higher content of Th, $\mathrm{U}$ and REE elements, low CL emission and narrowly-spaced oscillatory zoning patterns. As shown in the $\mathrm{U}_{-}{ }^{206} \mathrm{~Pb} /{ }^{238} \mathrm{U}$ age diagram (Fig. 11d), the ${ }^{206} \mathrm{~Pb} /{ }^{238} \mathrm{U}$ ages of the ESZ are relatively scattered, while the ${ }^{206} \mathrm{~Pb} /{ }^{238} \mathrm{U}$ age of the LSZ are mainly concentrated around $157-158$ Ma. This 
https://doi.org/10.5194/se-2021-129

Preprint. Discussion started: 17 November 2021

(c) Author(s) 2021. CC BY 4.0 License.

\section{(c) (i)}

phenomenon indicates that the cooling rate of magma in the deeper magma chamber was relatively slow, thus the zircon crystallized continuously over a relatively long period. The magma finally solidified in a relatively short period, so the zircon crystallized rapidly.

Zircon U-Pb dating is the most commonly used method in magmatic rock dating. A weighted mean age or upper intercept age is usually obtained to represent the emplacement time of a magmatic rock. However, this study shows that zircons in magmatic rocks record two different magmatic evolution stages: in the deeper magma chamber and in the ascent passage or/and emplacement site. Previous studies, such as Wang et al. (2007), Zhao et al. (2014) and Chen et al. (2020), also show that zircons can crystallize continually or intermittently in a single phase of magmatism, showing several growth zones of clearly different internal structure and distinct time difference. Some scholars even regard that the age difference of different stages can be more than dozens of Ma (Wang et al., 2007). Therefore, if the zircon ages in the same magmatic rock have a large range of variation, this could be caused by the zircons recording different stages in magmatic evolution, related to different levels of magma within the crust and/or different temperature regimes. It is notable that the bulk petrology and geochemistry of the host pluton does not record and reveal this two-stage magmatic evolution, which can only be detected in the zircon analysis.

\subsection{Genetic type: I-type affinity}

The samples of the Zhoujiapuzi granite have $\mathrm{A} / \mathrm{KNC}<1.1$, relatively high $\mathrm{Na}_{2} \mathrm{O}$ (3.96-4.65 wt.\%) and lack peraluminous minerals (e.g. cordierite, andalusite, muscovite and garnet), which are clearly different from S-type granites (Chappell and White, 1992). With the rise of the degree of crystallization, $\mathrm{P}_{2} \mathrm{O}_{5}$ contents (generally $>0.1 \mathrm{wt} \%$ ) increase in S-type granites, accompanied by an increase/immutability in $\mathrm{SiO}_{2}$ (Wolf and London, 1994). However, the Zhoujiapuzi granite samples have low $\mathrm{P}_{2} \mathrm{O}_{5}$ contents $\left(0.02-0.08\right.$ wt.\%), and decrease with increasing $\mathrm{SiO}_{2}$ (Fig. 12a), which is also inconsistent with the characteristics of S-type granite (Chappell and White, 1992). Additionally, Rb has a negative correlation with Y (Fig. 12b), which has been considered as an indicator of I-type granite rather than S-type granite (Jiang et al., 2018). Thus, the Zhoujiapuzi granite is not an S-type granite.

Although the samples of the Zhoujiapuzi granite have high 10000Ga / Al ratios of (2.74-3.13) akin to A-type granites, the low $\mathrm{Zr}(113-242 \mathrm{ppm})$ and $\mathrm{Zr}+\mathrm{Nb}+\mathrm{Ce}+\mathrm{Y}(152.0-382.6 \mathrm{ppm})$ contents are distinct from the diagnostic features of A-type granites (Whalen et al., 1987). This observation is consistent with the Zhoujiapuzi granite lacking alkaline mafic minerals (Zhang et al., 2017). Wu et al. (2017) suggested that a high formation temperature is one of the most important characteristics of A-type granite. Zircon saturation thermometry (Tzrn) and Ti-in-zircon thermometer (Tzr-Ti) are two methods for estimating magma temperatures. As discussed before, $\mathrm{T}_{\mathrm{Zr}-\mathrm{Ti}}$ is negatively correlated with the $\mathrm{U}$ content, which indicates that the crystallization temperature of zircon gradually decreases with magma. Hence, the initial magma temperature should be greater than or equal to the highest Ti temperature $\left(792{ }^{\circ} \mathrm{C}\right)$. Zircon saturation thermometry was introduced by Watson and Harrison (1983) and is suitable for non-peralkaline crustal source rocks. The calculated TZrn values for the Zhoujiapuzi granite are in the range of $803-870{ }^{\circ} \mathrm{C}$. Because the Zhoujiapuzi granite contains abundant inherited zircons, the initial 
https://doi.org/10.5194/se-2021-129

Preprint. Discussion started: 17 November 2021

(c) Author(s) 2021. CC BY 4.0 License.

\section{(c) (1)}

magma temperature should be lower than or equal to the lowest $T_{Z n}\left(803{ }^{\circ} \mathrm{C}\right)$ (Miller et al., 2003). Therefore, the initial magma temperature of the Zhoujiapuzi granite was at a range of $792-803{ }^{\circ} \mathrm{C}$, which is significantly lower than that of the typically A-type granite $\left(>900^{\circ} \mathrm{C}\right.$, Skjerlie and Johnston, 1992; Douce, 1997). Furthermore, the Zhoujiapuzi granite samples show similar trends to the Late Jurassic granitoids in the Liaodong peninsula, which are typical I-type granites (Fig. 12). Therefore, we conclude that the Zhoujiapuzi granite is a highly fractionated I-type granite.

\subsection{Petrogenesis of the high $\mathrm{Sr} / \mathrm{Y}$ granite}

The samples of the Zhoujiapuzi granite have high $\mathrm{Sr} / \mathrm{Y}$ and $(\mathrm{La} / \mathrm{Yb})_{\mathrm{N}}$ ratios and low $\mathrm{Y}$ and $\mathrm{Yb}$ contents (Fig. 13a) consistent with the geochemical signatures of modern adakites (Defant and Drummond, 1990). However, other geochemical parameters of the Zhoujiapuzi granite, such as the high $\mathrm{K}_{2} \mathrm{O} / \mathrm{Na}_{2} \mathrm{O}$ ratio $(0.93-1.22)$, low $\mathrm{Al}_{2} \mathrm{O}_{3}$ content (14.49-15.02\%, except one) and $\mathrm{Sr}$ content (in half of the samples lower than $400 \mathrm{ppm}$ ), are obviously different from typical adakites $\left(\mathrm{K}_{2} \mathrm{O} / \mathrm{Na}_{2} \mathrm{O} \leqslant 0.42\right.$, $\mathrm{Al}_{2} \mathrm{O}_{3} \geqslant 15 \%, \mathrm{Sr}>400$ ppm, Defant and Drummond., 1990; Drummond et al., 1996, Martin et al., 2005). A variety of petrogenetic models have been proposed for the origin of high $\mathrm{Sr} / \mathrm{Y}$ magmatic rocks, such as partial melting of subducting oceanic crust (Model A, Defant and Drummond, 1990), delaminated lower continental crust (LCC) (Model B, Kay and Kay, 1993; Xu et al., 2002), differentiation of basaltic arc magma (Model C, Castillo et al., 1999), magma mixing between mantle-derived mafic and crust-derived silicic magmas (Model D, Ma et al., 2013), partial melting of thickened basaltic LCC (Model E, Gao et al., 2004; Ou et al., 2017), or melting of a high Sr/Y (and La/Yb) source (Model F, Kamei et al., 2009; Ma et al., 2015).

\subsubsection{Model A: Partial melting of subducting oceanic crust}

275 The partial melting of the young, hot and hydrated subducted oceanic slab in the garnet stability field is the classical formation model of adakite (high Sr/Y rock) (Defant and Drummond, 1990). Studies have shown that the rock with this genetic model generally has the characteristics of high mantle components (such as $\mathrm{MgO}, \mathrm{CaO}$ and $\mathrm{Cr}$ ) because of the involvement of mantle magma (Wang et al., 2018). However, this phenomenon was not seen in the Zhoujiapuzi granite. In addition, the Zhoujiapuzi granite has high $\mathrm{K}_{2} \mathrm{O} / \mathrm{Na}_{2} \mathrm{O}$ ratios $(0.92-1.22$, average 1.13), which is inconsistent with the slabderived adakites $\left(\mathrm{K}_{2} \mathrm{O} / \mathrm{Na}_{2} \mathrm{O}=\sim 0.4\right.$, Martin et al., 2005). Moreover, the low $\varepsilon \mathrm{Hf}(\mathrm{t})$ values (-26.3 to -22.8) of the Zhoujiapuzi granite are also inconsistent with the magmas derived from the partial melting of oceanic crust, which generally have depleted isotopic character (Zhan et al., 2020). In summary, the Zhoujiapuzi granite is difficult to explain by Model A.

\subsubsection{Model B: Delaminated lower continental crust (LCC)}

High-density, garnet-bearing mafic lower crust delaminating or foundering into the asthenosphere mantle and subsequent 285 interaction with mantle peridotite could produce high Sr/Y magmas (Kay and Kay 1993). Because the melt formed by partial melting of the delaminated lower crust would interact with mantle peridotite during magma ascent, the high $\mathrm{Sr} / \mathrm{Y}$ magmas 
https://doi.org/10.5194/se-2021-129

Preprint. Discussion started: 17 November 2021

(c) Author(s) 2021. CC BY 4.0 License.

\section{(c) (1)}

related to this petrogenetic model generally have high $\mathrm{MgO}$ (>1.5\%) and $\mathrm{Mg} \#$ ( $>50)$ (Gao et al., 2004; Ou et al., 2017). The $\mathrm{MgO}(0.10-0.44)$ and $\mathrm{Mg \#}(15-26)$ values of Zhoujiapuzi granite are significantly lower than the above values. Due to the high temperature of the asthenosphere $\left(1200{ }^{\circ} \mathrm{C}\right.$, Parsons and McKenzie, 1978; King et al., 2015), rocks formed by partial melting of the delaminated lower crust should possess a high-temperature fingerprint. As mentioned before, the initial magma temperature of the Zhoujiapuzi granite was $\sim 800{ }^{\circ} \mathrm{C}$, which is markedly lower than the temperature of the asthenosphere. Therefore, the petrogenetic model of delaminated lower continental crust (Model B) is also inconsistent with the Zhoujiapuzi granite.

\subsubsection{Model C: Differentiation of basaltic arc magma}

Low-pressure fractional crystallization (involving olivine + clinopyroxene + plagioclase + amphibole + titanomagnetite) or high-pressure fractional crystallization (involving garnet) from basaltic magmas have been proposed as two ways to generate adakitic characteristics (Castillo et al., 1999; Macpherson et al., 2006). As shown in the La/Sm versus La diagram (Fig. 14a), increasing La content with constant $\mathrm{La} / \mathrm{Sm}$ shows that fractional crystallization rather than partial melting is the main factor controlling the composition of the Zhoujiapuzi granite. Hence, the samples of Zhoujiapuzi granite displayed variable Eu and

$300 \mathrm{Sr}$ contents, implying that the plagioclase is likely a fractional phase. Separation of titanomagnetite could explain the positive in $\mathrm{TFe}_{2} \mathrm{O}_{3}$ with increasing $\mathrm{TiO}_{2}$ content (Fig. 14b), consistent with the occurrences of magnetite in some studied rocks. This possible mineral assemblage of fractional crystallization is also reflected by the chemical variations in the $\mathrm{Sr} / \mathrm{Y}-\mathrm{Y}$ diagram (Fig. 13b).

However, fractionation of olivine and clinopyroxene is inconsistent with the depletion of HREE (e.g., Yb) given their

low distribution coefficients for these elements in mafic-intermediate magmas (Dunn and Sen, 1994). Moreover, the crystallization of amphibole would result in a negative correlation between the $(\mathrm{Dy} / \mathrm{Yb})_{\mathrm{N}}$ and $(\mathrm{La} / \mathrm{Yb})_{\mathrm{N}}(\mathrm{Davidson}$ et al., 2007), which is not seen in the Zhoujiapuzi granite (Fig. 14c). No positive correlations between $\mathrm{Dy} / \mathrm{Yb}$ and $\mathrm{Sr} / \mathrm{Y}$ ratios and $\mathrm{SiO}_{2}$ contents (Figure 14d, e) suggest that fractional crystallization of garnet was not a significant process for the Zhoujiapuzi granite (Macpherson et al., 2006). Therefore, both the low-pressure and high-pressure crystallization fractionation of basaltic melts could be ruled out for the negligible fractional crystallization of olivine, clinopyroxene, garnet and amphibole.

In addition, crystal fractionation of basaltic melts can only form minor volumes of granitic melts, the ratio of the two is about 9:1 (Zeng et al., 2016). However, in the Liaodong Peninsula, most of the Middle-Late Jurassic magmatic rocks are acidic, mafic-ultramafic rocks are only reported in the Huaziyu area (lamprophyre dikes, Jiang et al., 2005), and cover a

315 much smaller area than the Zhoujiapuzi granite. For these reasons, it is highly improbable that Zhoujiapuzi granite was derived by differentiation of basaltic magma (Model C).

\subsubsection{Model D: Magma mixing between mantle-derived mafic and crust-derived silicic magmas}

The Zhoujiapuzi granite has high $\mathrm{K}_{2} \mathrm{O} / \mathrm{Na}_{2} \mathrm{O}$ ratio $(>1)$ and $\mathrm{A} / \mathrm{CNK}$ value $(>1)$, together with the absence of mafic 
https://doi.org/10.5194/se-2021-129

Preprint. Discussion started: 17 November 2021

(c) Author(s) 2021. CC BY 4.0 License.

\section{(c) (1)}

microgranular enclaves (MMEs), felsic xenocrysts and melting texture of plagioclase, implying that the mantle-derived magma is unlikely to have played an important role in the genesis of the Zhoujiapuzi granite (Castro et al., 1991). In addition, the Zhoujiapuzi granite is characterized by the development of biotite, but lacks amphibole and pyroxene. These features, coupled with the high $\mathrm{A} / \mathrm{CNK}$ value, are consistent with an origin as a crust-derived granitoid, but obviously different from the granitoids formed by crust-mantle-derived magma mixing (Barbarin, 1990). Moreover, granites formed by magma mixing generally have variations in $\varepsilon \mathrm{Hf}(\mathrm{t})$ values, high $\mathrm{MgO}, \mathrm{TFe}_{2} \mathrm{O}_{3}, \mathrm{CaO}$ and $\mathrm{Cr}$ contents and low $\mathrm{SiO}_{2}$ content (Ma et al., 2013; Wang et al., 2018). These features are obviously inconsistent with the Zhoujiapuzi granite in this study. Hence, magma mixing of mantle-derived and crust-derived magmas (Model D) is also unlikely to have produced the Zhoujiapuzi granite.

\subsubsection{Model E: Partial melting of thickened basaltic LCC}

Experimental studies have shown that the partial melt of basaltic LCC in the garnet stabilization zone ( $>40 \mathrm{~km}$, i.e. $\sim 1.2$ GPa) can produce magma with a high Sr/Y ratio (Rapp et al., 2003 and references therein). In these scenarios, high Sr/Y and overall adakitic affinity are caused by leaving garnet as residual phases (e.g. Gao et al., 2004). Based on geochemical data for the Zhoujiapuzi granites, partial melting of thickened basaltic LCC is also unlikely to account for the high $\mathrm{Sr} / \mathrm{Y}$ Zhoujiapuzi granite (Model E). This conclusion is based on the following observations:

(1) This ratio of $(\mathrm{Gd} / \mathrm{Yb})_{\mathrm{N}}$ is the most important feature to judge whether garnet is involvement in magma genesis (Ma et al., 2012). If the $(\mathrm{Gd} / \mathrm{Yb})_{\mathrm{N}}$ ratio of the source is similar to the average value of the LCC (1.71, Rudnick and Gao, 2003), partial melting of these crustal materials controlled by garnet at high pressure can produce melt with $(\mathrm{Gd} / \mathrm{Yb})_{\mathrm{N}}$ of 5.8 (Huang and $\mathrm{He}, 2010)$. In contrast, the $(\mathrm{Gd} / \mathrm{Yb})_{\mathrm{N}}$ values (1.22-5.06, average 2.69) of the Zhoujiapuzi granite are relatively low. (2) Melt in equilibrium with a garnet-rich residue will result in positive correlations between the $\mathrm{Dy} / \mathrm{Yb}$ and $\mathrm{Sr} / \mathrm{Y}$ ratios and $\mathrm{SiO}_{2}$ contents. However, these phenomena were not seen in the Zhoujiapuzi granite (Fig.14 d, e). (3) Studies of lower-crustal xenoliths show that garnet may not be a common mineral in the lower crust of the NCC (Huang et al., 2004; Ma et al., 2012).

340 (4) As shown in the discrimination diagrams of granite sources (Fig. 14f, g), all samples fall in the range of metagreywackederived melts. Therefore, the Zhoujiapuzi granite was considered to have been derived from crustal anatexis of metagraywacke (or intermediate-acid igneous rock with similar mineral composition), rather than basaltic lower crust.

\subsubsection{Model F: Melting of a high Sr/Y (and La/Yb) source}

Studies have shown that when a source rock has a high $\mathrm{Sr} / \mathrm{Y}$ ratio, the high $\mathrm{Sr} / \mathrm{Y}$ signature of the derived magma can inherit

345 from their source, regardless of pressure (Kamei et al., 2009; Moyen, 2009; Ma et al., 2015). The Zhoujiapuzi granite has similar $\mathrm{K}_{2} \mathrm{O} / \mathrm{Na}_{2} \mathrm{O}$ ratios and $\mathrm{Al}_{2} \mathrm{O}_{3}$ contents to the Tsutsugatake intrusion (Fig. 14h), which is explained by partial melting of arc-type tonalite or adakitic granodiorite (Kamei et al., 2009). We suggest that partial melting of high $\mathrm{Sr} / \mathrm{Y}$ Liaoji granite was most probably the origin of the high Sr/Y Zhoujiapuzi granite, as discussed below (Model F).

Among the inherited zircons from Zhoujiapuzi granite, the ${ }^{207} \mathrm{~Pb} /{ }^{206} \mathrm{~Pb}$ ages of all the spots are between 2132 and 2200 
https://doi.org/10.5194/se-2021-129

Preprint. Discussion started: 17 November 2021

(c) Author(s) 2021. CC BY 4.0 License.

\section{(c) (i)}

melting of source rocks can explain the genesis of inherited zircon in granite. Due to the similar $\mathrm{T}_{\mathrm{DM} 2}$ of syn-magmatic zircons (ESZ and LSZ) and the $\sim 2.17 \mathrm{Ga}$ inherited zircon, the $\sim 2.17 \mathrm{Ga}$ inherited zircons most likely come from the source of the Zhoujiapuzi granite. In the study area, meta-sedimentary rocks and meta-volcanic rocks of the South Liaohe Group, $\sim 2.17 \mathrm{Ga}$ mafic rocks, as well as the Liaoji granites, have $\sim 2.17 \mathrm{Ga}$ zircon. In spite of an age peak of $\sim 2.17 \mathrm{Ga}$ in detrital zircon age spectra of the metasediments from the South Liaohe Group, melting of a sediment-dominated source is unlikely to have occurred, as it would have also introduced other age peaks such as $\sim 2.03 \mathrm{Ga}$ and $2.09 \mathrm{Ga}$ (Li et al., 2015). In addition, given the I-type characteristics of the Zhoujipuzi granite, derivation from an igneous precursor is more plausible rather than a metasedimentary origin (Chappell and White, 1992). Therefore, these $\sim 2.17 \mathrm{Ga}$ zircon from Zhoujiapuzi granite is unlikely to come from the South Liaohe Group. As shown in the host rock discrimination diagrams (Fig. 15, introduced by Belousova et al., 2002), all the $\sim 2.17 \mathrm{Ga}$ inherited zircons from Zhoujiapuzi granite fall into the granitoid area (Fig. 15), precluding that these $\sim 2.17 \mathrm{Ga}$ zircon come from the $\sim 2.17 \mathrm{Ga}$ mafic rocks. In addition, the $\sim 2.17 \mathrm{Ga}$ inherited zircons from Zhoujiapuzi granite and the zircons from the Liaoji granites lie in a similar area in the $\varepsilon \mathrm{Hf}(\mathrm{t})$-age (Ma) diagram (Fig. 9). Hence, the $\sim 2.17$ Ga inherited zircon most likely come from the Liaoji granites.

Some of the Liaoji granites, such as the Muniuhe granite (comprising granodiorite and syenogranite with no distinct boundary between the two), have adakitic signatures, and similar REE and trace element patterns as the Zhoujiapuzi granite (Fig. 4). Based on a model of modal batch melting (Shaw, 1970) using the experiments of Conrad et al. (1988), the high $\mathrm{Sr} / \mathrm{Y}$ characteristic of the Zhoujiapuzi granite can be explained by partial melting of Muniuhe granitic pluton leaving amphibole as the main residue (Fig. 13b). In this model, we choose the XY-005 sample to approximately represent a primitive melt composition because the fractional crystallization of plagioclase decreased of $\mathrm{Sr}$ content and $\mathrm{Sr} / \mathrm{Y}$ ratio (Fig. 13a). To find the best matching experimental melts, we have compared the major elements of the XY-005 sample with that of experimental melts, coupled with the initial magma temperature of $\sim 800{ }^{\circ} \mathrm{C}$ and the characteristics of no garnet residue discussed above. Results are shown in Fig. 13b. The Sr and Y compositions of the starting material used in these experiments resemble those of the average composition of the Muniuhe granitic pluton ( $\mathrm{Sr}=475 \mathrm{ppm}, \mathrm{Y}=9.77 \mathrm{ppm}$ ), if the residue contains a large volume of amphibole (>90\%). However, if more plagioclase is retained in the residue (e.g. $18.3 \%$ ), a source region with a higher $\mathrm{Sr}$ content is required. Therefore, a similar high $\mathrm{Sr} / \mathrm{Y}$ Liaoji granite to the Muniuhe granitic pluton can produce the high $\mathrm{Sr} / \mathrm{Y}$ signatures of the Zhoujiapuzi granite.

A large number of Yanshanian adakites (or high Sr/Y rocks) are developed in the NCC, which are generally considered to be derived from the thickened basaltic LCC (e.g. Gao et al., 2004; Wu et al., 2005; Ma et al., 2013). Zhang et al. (2001, 2003) suggested that these so-called "C-type adakites" indicated a large-scale crustal thickening event, so it was speculated that a Mesozoic plateau once existed in the eastern China. However, according to the studies on the Triassic and Jurassic adakitic rocks near the Pingquan area, the northern part of the NCC, Ma et al. $(2012,2015)$ suggested that the adakitic signatures of these rocks are inherited from their source rocks. Similar results have been obtained by studying the late Jurassic Zhoujiapuzi granite in the Liaodong Peninsula in this study. Therefore, we suggest that melting of a high $\mathrm{Sr} / \mathrm{Y}$ (and $\mathrm{La} / \mathrm{Yb}$ ) source is an important process for the generation of Yanshanian high $\mathrm{Sr} / \mathrm{Y}$ rocks in the NCC. This kind of high $\mathrm{Sr} / \mathrm{Y}$ 
https://doi.org/10.5194/se-2021-129

Preprint. Discussion started: 17 November 2021

(c) Author(s) 2021. CC BY 4.0 License.

(c) (i)

385 granite does not need to be formed in the garnet stability field.

\subsection{Tectonic implications}

A large number of Early Jurassic arc-like igneous rocks occur in the northeast part of NCC- Korean Peninsula-Hida belt, which belong to the middle-high K calc-alkaline series and are characterized by the enrichment in LILE and depletions in HFSE (Wu et al., 2007; Tang et al., 2018 and references therein). In addition, the Early Jurassic accretionary complexes in

390 the eastern margin of the Eurasian continent and the Japan islands, such as the Heilongjiang complex, the Khabarovsk complex and the Mino-Tamba complex, are considered to be related to subduction (Wu et al., 2007; Tang et al., 2018 and references therein). It is generally accepted that the Paleo-Pacific slab subducted westwards in the Early Jurassic (Tang et al., 2018; Zhu and Xu, 2018).

In the middle-late Jurassic, I-type granites are dominant in the Liaodong Peninsula, such as the Zhoujiapuzi granite (this study), Heigou pluton, Gaoliduntai pluton (Wu et al., 2005a), Waling granite (Yang et al., 2015b) and Sanguliu granite (Yang et al., 2018). There are not A-type granites, and mantle derived magmatism is extremely rare. These granites were formed by partial melting of crustal materials without obvious contribution of mantle derived magma (Wu et al., 2005a; Yang et al., 2015b, 2018; Xue et al., 2020). In addition, WNW-ESE compression during 157-143 Ma was widespread in the Liaodong Peninsula (Yang et al., 2004; Zhang et al., 2020). It not only mylonitized the granite plutons in middle-lower crust

400 levels, but also intensely deformed the thick sedimentary cover in the upper crust (Qiu et al., 2018; Ren et al., 2020). Low angle subduction will lead to the separation of lithospheric mantle and asthenospheric mantle, which will lead to tectonic compression, a cold orogeny and a lack of mafic magmatism (Zheng et al., 2018). Hence, the Late Jurassic magmatism in the Liaodong peninsula is most likely to be related to the thinning of the NCC mantle lithosphere, itself triggered by the subduction of the Paleo-Pacific plate (Zheng et al., 2018). A likely setting is a mature continental arc, with crust previously thickened by compressional tectonics, related to both the oceanic subduction and the earlier Mesozoic collisions at the north and south margins of the NCC. There is a potential resemblance to the modern arc of the Central Andes (Allmendinger et al., 1997), where crustal thickening and plateau growth has developed over the Cenozoic (Scott et al., 2018), and melting of older basement has taken place during subduction of the Nazca plate (Miller and Harris, 1989).

\section{Conclusion}

(1) LA-ICP-MS zircon U-Pb dating indicates that the Zhoujiapuzi granite in the Liaodong Peninsula formed during the Late Jurassic (158-162 Ma).

(2) Zircon growth in Zhoujiapuzi granite can be divided into two distinct stages, the ESZ and LSZ. The ESZ was formed in a deeper, hotter, magma chamber, which had low oxygen fugacity and high temperature. Whereas, the LSZ formed from later, more evolved, magma. Oxygen fugacity significantly increased and the temperature decreased at this 
https://doi.org/10.5194/se-2021-129

Preprint. Discussion started: 17 November 2021

(c) Author(s) 2021. CC BY 4.0 License.

(c) (i)

415 stage. The Zhoujiapuzi granite is a case study of multistage generation and emplacement of magma, revealed by zircons, where no signals are discernible in the bulk petrology or geochemistry.

(3) The I-type Zhoujiapuzi granite originated from partial melting of the $\sim 2.17$ Ga Liaoji granites. The high $\mathrm{Sr} / \mathrm{Y}$ compositions are inherited from their source rocks, rather than being a direct indication of deep crustal melting, or any other common mechanism for generating adakitic signatures.

(4) The Late Jurassic tectonic setting of the Liaodong Peninsula and the eastern NCC resembled the modern orogenic plateau of the Central Andes, where silicic magmatism may occur by partial melting of older continental crust in a compressional environment related to the subduction of the Paleo-Pacific plate.

Data availability. The data presented in the supplement.

425 Supplement. The supplement related to this article (Tables S1, S2, S3, S4 and S5) is available online at:

Author contributions. Renyu Zeng: Conceptualization, Methodology, Writing - original draft. Mark B. Allen: Writing review \& editing; Xiancheng Mao: Funding acquisition, Project administration; Jianqing Lai: Funding acquisition. Jie Yan: Writing - review \& editing. Jianjun Wan: Visualization.

Competing interests. The contact author has declared that neither they nor their co-authors have any competing interests

430 Acknowledgements

We thank Dr. Wenzhou Xiao, Dr. Jiajie Chen for constructive reviews and useful suggestions. We are also grateful to Ying Liu, Chunying Guo, Jianxiong Hu, Ziming Hu for their help with the field work. This research was funded by the National Nature Science Foundation of China (Grants No. 41772349, 42030809 and 41902075), China Scholarship Council (No. 202008360018), Geological Exploration Program of China Nuclear Geology (Grant No. D1802), the research grants from

435 the East China University of Technology (Grant No. DHBK2017103), Open Research Fund Program of State Key Laboratory of Nuclear Resources and Environment (East China University of Technology) (Grant 2020NRE13).

\section{References}

Allmendinger, R.W., Jordan, T.E., Kay, S.M. and Isacks, B.L.: The evolution of the Altiplano-Puna plateau of the Central Andes. Annu. Rev. Earth Planet. Sci. 25, 139-174, 1997.

440 Altherr, R., Holl, A., Hegner, E., Langer, C. and Kreuzer, H.: High-potassium, calc-alkaline I-type plutonism in the European Variscides: northern Vosges (France) and northern Schwarzwald (Germany). Lithos 50(1-3), 51-73, 2000.

Ballard, J. R., Palin, M. J., Campbell, I. H.: Relative oxidation states of magmas inferred from Ce(IV)/Ce(III) in zircon: application to porphyry copper deposits of northern Chile. Contrib. Mineral. Petrol. 144, 347-364, 2002. 
https://doi.org/10.5194/se-2021-129

Preprint. Discussion started: 17 November 2021

(c) Author(s) 2021. CC BY 4.0 License.

(c) (i)

Barbarin, B.: Granitoids: main petrogenetic classifification in relation to origin and tectonic setting. Geol. J. 25, 227-238, 1990.

Belousova, E., Griffin, W., O'Reilly, S. Y., and Fisher, N.: Igneous zircon: trace element composition as an indicator of source rock type. Contrib. Mineral. Petrol. 143, 602-622, 2002.

Blichert-Toft, J., and Albarède, F.: The Lu-Hf isotope geochemistry of chondrites and the evolution of the mantle-crust system. Earth Planet. Sci. Lett. 148(1), 243-258, 1997.

Breiter, K., Lamarão, C. N., Borges, R. M. K., and Dall'Agnol, R.: Chemical characteristics of zircon from A-type granites and comparison to zircon of S-type granites. Lithos 192-195, 208-225, 2014.

Cao, W., Paterson, S., Memeti, V., Mundil, R., Anderson, J.L., and Schmidt, K.: Tracking paleodeformation fields in the Mesozoic Central Sierra Nevada arc: Implications for intra-arc cyclic deformation and arc tempos. Lithosphere 7 (3), 296-320. https:// doi.org/10.1130/L389.1, 2015

Castillo, P. R., Janney, P. E., and Solidum, R. U.: Petrology and geochemistry of Camiguin Island, southern Philippines: Insights to the source of adakites and other lavas in a complex arc setting, Contrib. Mineral. Petrol., 134(1), 33-51, 1999.

Castillo, P.R., Janney, P.E., and Solidum, R.U.: Petrology and geochemistry of Camiguin Island, southern Philippines: Insights to the source of adakites and other lavas in a complex arc setting. Contrib. Mineral. Petrol. 134, 33-51, 1999.

Castro, A., Moreno-Ventas, I., and Rosa, J.: H-type (hybrid) granitoids: a proposed revision of the granite-type classification and nomenclature. Earth-Sci Rev 31, 237-253, 1991.

Chen, S.R., Wang, Q., Zhu, D.C., Weinberg, R.F., Zhang, L.L., and Zhao, Z.D.: Reheating and magma mixing recorded by zircon and quartz from high-silica rhyolite in the Coqen region, southern Tibet. Am. Miner. https://doi.org/10.2138/am2020-7426, 2020.

465 Conrad, W.K., Nicholls, I.A., and Wall, V.J.: Water-saturated and -undersaturated melting of metaluminous and peraluminous crustal compositions at $10 \mathrm{~kb}$ : evidence for the origin of silisic magmas in the Taupo Volcanic Zone, New Zealand, and other occurrences. Journal of Petrology 29, 765-803, 1988.

Davidson, J., Turner, S., Handley, H., Macpherson, C., and Dosseto, A.: Amphibole "sponge" in arc crust? Geology, 35(9), 787-790, 2007.

470 DeCelles, P.G., Ducea, M.N., Kapp, P., and Zandt, H.G.: Cyclicity in Cordilleran orogenic systems. Nat. Geosci. 2, 251-257, 2009.

Defant, M. J., and Drummond, M. S.: Derivation of some modern arc magmas by melting of young subducted lithosphere. Nature 347, 662-665, 1990.

Drummond, M.S., Defant, M.J., and Kepezhinskas, P.K.: Petrogenesis of slab-derived trondhjemite-tonalite-dacite/adakite magmas. Trans. R. Soc. Edinb. 87, 205-215, 1996.

Ducea, M.N., Paterson, S.R., and DeCelles, P.G.: High-volume magmatic events in subduction systems. Elements 11, 99$104,2015$. 
https://doi.org/10.5194/se-2021-129

Preprint. Discussion started: 17 November 2021

(c) Author(s) 2021. CC BY 4.0 License.

(c) (i)

Dunn, T., and Sen, C.: Mineral/matrix partition coefficients for orthopyroxene, plagioclase, and olivine in basaltic to andesitic systems: A combined analytical and experimental study, Geochim. Cosmochim. Acta, 58(2), 717-733, 1994.

Ferry, J. M., and Watson, E. B.: New thermodynamic models and revised calibrations for the Ti-in-zircon and Zr-in-rutile thermometers. Contrib. Mineral. Petrol. 154, 429-437, 2007.

Frost, B. R., Barnes, C. G., Collins, W. J., Arculus, R. J., Ellis, D. J., and Frost, C. D.: A geochemical classification for granitic rocks. J. Petrol. 42, 2033-2048, 2001.

Gao, S., Rudnick, R. L., Yuan, H.L., Liu, X.M., Liu, Y.S., Xu, W.L., Ling, W.L., Ayers, J. C., Wang, X.C., and Wang, Q.H.: Recycling lower continental crust in the North China craton. Nature 432, 892-897, 2004.

Gutscher, M., Maury, R., Eissen, J. P., and Bourdon, E.: Can slab melting be caused by flat subduction? Geology 28, 535$538,2000$.

Harrison, T.M., Watson, E.B., and Aikman, A.B.: Temperature spectra of zircon crystallization in plutonic rocks. Geology 35 (7), 635-638, 2007.

Hoskin, P. W. O.: Trace-element composition of hydrothermal zircon and the alteration of Hadean zircon from the Jack Hills, Australia. Geochim. Cosmochim. Acta 69, 637-648, 2005.

Hoskin, P. W., and Schaltegger, U.: The composition of zircon and igneous and metamorphic petrogenesis. Rev. Mineral. Geochem. 53, 27-62, 2003.

Huang, F., and He, Y.S.: Partial melting of the dry mafic continental crust: Implications for petrogenesis of C-type adakites. Chin. Sci. Bull. 55, 1255-1267, 2010.

Jiang, Y.H., Jiang, S.Y., Zhao, K.D., Ni, P., Ling, H.F., and Liu, D.Y.: SHRIMP U-Pb zircon dating for lamprophyre from Liaodong Peninsula: Constraints on the initial time of Mesozoic lithosphere thinning beneath eastern China. Chin. Sci. Bull. 50, 2612-2620, 2005.

Kai, Z. A., Zl, B., Zx, B., C, X. X., Wang, A., Wc, B., and Yhb, D.: Petrogenesis and tectonic implications of two types of Liaoji granitoid in the Jiao-Liao-Ji Belt, North China Craton. Precambrian Res 331, 105369, 2019.

Kamei, A., Miyake, Y., Owada, M., and Kimura, J.: A pseudo adakite derived from partial melting of tonalitic to granodioritic crust, Kyushu, southwest Japan arc. Lithos 112, 615-625, 2009.

Kay, R. W., and Kay, S. M.: Delamination and delamination magmatism. Tectonophysics 219, 177-189, 1993.

King, S. D., Frost, D. J., and Rubie D. C.: Why cold slabs stagnate in the transition zone, Geology, 43(3), 231-234, 2015.

Kusky, T.M., Windley, B.F., Wang, L., Wang, Z.S., Li, X.Y., and Zhu, P.M.: Flat slab subduction, trench suction, and craton destruction: Comparison of the North China, Wyoming, and Brazilian cratons. Tectonophysics 630, 208-221, 2014.

Langmuir, C.H., Vocke, R.D., Hanson, G.N., and Hart, S.R.: A general mixing equation with applications to Icelandic basalts. Earth Planet. Sci. Lett. 37, 380-392, 1978. 
https://doi.org/10.5194/se-2021-129

Preprint. Discussion started: 17 November 2021

(c) Author(s) 2021. CC BY 4.0 License.

(c) (i)

Li C, Chen B, Li Z and Yang C.: Petrologic and geochemical characteristics of Paleoproterozoic monzogranitic gneisses from Xiuyan-Kuandian area in Liaodong Peninsula and their tectonic implications. Acta Petrologica Sinica, 33 ( 3 ) : 963 - 977, 2017 (In Chinese with English abstract).

Li, C., Chen, B., Li, Z., and Yang, C.: Petrologic and geochemical characteristics of Paleoproterozoic monzogranitic gneisses from Xiuyan-Kuandian area in Liaodong Peninsula and their tectonic implications. Acta Petrologica Sinica, 33(3): 963-977, 2017 (In Chinese with English abstract).:

515 Li, C.M., Zhang, C.H., Cope, T.D., and Lin, Y.: Out-of-sequence thrusting in polycyclic thrust belts: An example from the Mesozoic Yanshan belt, North China Craton. Tectonics 35: 2082-2116, 2016.

Li, S.Z., Liu, J.Z., Zhao, G.C., Wu, F.Y., Han, Z.Z., and Yang, Z.Z.: Key geochronology of Mesozoic deformation in the eastern block of the North China Craton and its constraints on regional tectonics: A case of Jiaodong and Liaodong Peninsula. Acta. Petrol. Sin. 2, 633-646, 2004.

Li, Z., Chen, B., Liu, J.W., Zhang, L., and Yang, C.: Zircon U-Pb ages and their implications for the South Liaohe Group in the Liaodong Peninsula, Northeast China. Acta Petrol. Sin. 31(6), 1589-1605, 2015 (in Chinese with English abstract).

Liu, Y.S., Hu, Z.C., Zong, K.Q., Gao, C.G., Gao, S., Xu, J., and Chen, H.H.: Reappraisement and refinement of zircon U-Pb isotope and trace element analyses by LA-ICP-MS. Chin. Sci. Bull. 55, 1535-1546, 2010.

Lu, X. P., Wu, F. Y., Zhang, Y. B., Zhao, C. B., and Guo, C. L.: Emplacement age and tectonic setting of the Paleoproterozoic Liaoji Granites in Tonghua area, southern Jilin Province. Acta Petrol Sin 20, 381-392, 2004 (In Chinese with English abstract).

Ludwig, K. R.: User's manual for Isoplot 3.00: a geochronological toolkit for Microsoft Excel, Kenneth R. Ludwig, 2003.

Ma, L., Jiang, S.Y., Dai, B.Z., Jiang, Y.H., Hou, M.L., Pu, W., and Xu, B.: Multiple sources for the origin of Late Jurassic Linglong adakitic granite in the Shandong Peninsula, eastern China: Zircon U-Pb geochronological, geochemical and Sr-Nd-Hf isotopic evidence. Lithos 162-163, 251-263, 2013.

Ma, Q., Zheng, J.P., Griffin, W. L., Zhang, M., Tang, H.Y., Su, Y.P., and Ping, X.Q.: Triassic "adakitic" rocks in an extensional setting (North China): Melts from the cratonic lower crust. Lithos 149, 159-173, 2012.

Ma, Q., Zheng, J.P., Xu, Y.G., Griffin, W. L., and Zhang, R.S.: Are continental "adakites" derived from thickened or foundered lower crust? Earth Planet. Sci. Lett. 419, 125-133, 2015.

Ma, X.H., Chen, B., and Yang, M.C.: Magma mixing origin for the Aolunhua porphyry related to Mo-Cu mineralization, eastern Central Asian Orogenic Belt. Gondwana Res 24, 1152-1171, 2013.

Ma, X.H., Chen, B., and Yang, M.C.: Magma mixing origin for the Aolunhua porphyry related to Mo-Cu mineralization, eastern Central Asian Orogenic Belt. Gondwana Res. 24, 1152-1171, 2013.

Macpherson, C. G., Dreher, S. T., and Thirlwall, M. F.: Adakites without slab melting: High pressure differentiation of island arc magma, Mindanao, the Philippines, Earth Planet. Sci. Lett., 243(3), 581-593, 2006. 
https://doi.org/10.5194/se-2021-129

Preprint. Discussion started: 17 November 2021

(c) Author(s) 2021. CC BY 4.0 License.

(c) (i)

Maniar, P. D., and Piccoli, P. M.: Tectonic discrimination of granitoids. Geol. Soc. Am. Bull. 101, 635-643, 1989.

Martin, H., Smithies, R.H., Rapp, R., Moyen, J.-F., and Champion, D.: An overview of adakite, tonalite-trondhjemitegranodiorite (TTG), and sanukitoid: relationships and some implications for crustal evolution. Lithos 79, 1-24, 2005.

Meng, E., Liu, F.L., Liu, P.H., Liu, C.H., Yang, H., Wang, F., Shi, J.R., and Cai, J.: Petrogenesis and tectonic significance of Paleoproterozoic meta-mafic rocks from central Liaodong Peninsula, northeast China: Evidence from zircon $\mathrm{U}-\mathrm{Pb}$ dating and in situ Lu-Hf isotopes, and whole-rock geochemistry. Precambrian Res. 247, 92-109, 2014.

Meng, Q.R., Wei, H.H., Wu, G.L., and Duan, L.: Early Mesozoic tectonic settings of the northern North China Craton. Tectonophysics 611, 155-166, 2014.

Mezger, K., and Krogstad, E. J.: Interpretation of discordant U-Pb zircon ages: An evaluation. J. Metamorph. Geol. 15, 127140, 1997.

Miller, C. F., McDowell, S. M., and Mapes, R. W.: Hot and cold granites? Implications of zircon saturation temperatures and preservation of inheritance. Geology 31, 529-532, 2003.

Miller, J.F., and Harris, N.B.W.: Evolution of continental crust in the Central Andes; constraints from Nd isotope systematics. Geology, 17, 615-617, 1989.

Moyen, J.: High Sr/Y and La/Yb ratios: The meaning of the "adakitic signature". Lithos 112, 556-574, 2009.

Nasdala, L., Pidgeon, R. T., Wolf, D., and Irmer, G.: Metamictization and U-PB isotopic discordance in single zircons: a combined Raman microprobe and SHRIMP ion probe study. Miner. Petrol. 62, 1-27, 1998.

Nash, D.J., Ciborowski, T., Ullyott, J.S., Pearson, M.P. and Whitaker, K.A.: Origins of the sarsen megaliths at Stonehenge. Sci. Adv. 6, eabc0133, 2020.

Ou, Q., Wang, Q., Wyman, D. A., Zhang, H.X., Yang, J.H., Zeng, J.P., Hao, L.L., Chen, Y.W., Liang, H., and Qi, Y.: Eocene adakitic porphyries in the central-northern Qiangtang Block, central Tibet: Partial melting of thickened lower crust and implications for initial surface uplifting of the plateau. J. Geophys. Res. Solid Earth 122, 1025-1053, 2017.

Parsons, B., and Dan, M.K.: Mantle convection and the thermal structure of the plates. Journal of Geophysical Research: Solid Earth, 83, 1978.

Patiño Douce, A.E.: What do experiments tell us about the relative contributions of crust and mantle to the origin of granitic magmas? Geol. Soc. Lond. Spec. Publ. 168(1), 55-75, 1999.

Qi, G.W., Zhang, J.J., and Wang, M.: Mesozoic tectonic setting of rift basins in eastern North China and implications for destruction of the North China Craton. J. Asian Earth Sci. 111, 414-427, 2015.

Qiu, L., Kong, R.Y., Yan, D.P., Wells, M.L., Wang, A.P., Sun, W.H., Yang, W.X., Han, Y.G., Li, C.M., and Zhang, Y.X.: The Zhayao tectonic window of the Jurassic Yuantai thrust system in Liaodong Peninsula, NE China: Geometry, kinematics and tectonic implications. J. Asian Earth Sci. 164, 58-71, 2018.

Rapp, R. P., N. Shimizu, and M. D. Norman, Growth of early continental crust by partial melting of eclogite. Nature, 425(6958), 605-609, 2003. 
https://doi.org/10.5194/se-2021-129

Preprint. Discussion started: 17 November 2021

(c) Author(s) 2021. CC BY 4.0 License.

(c) (i)

Ren, Z.H., Lin, W., Faure, M., Meng, L.T., Qiu, H.B., and Zeng, J.P.: Triassic- Jurassic evolution of the eastern North China Craton: Insights from the Lushun-Dalian area, South Liaodong Peninsula, NE China. Geol. Soc. Am. Bull. https://doi.org/10.1130/B35533.1, 2020.

Rudnick, R. L., and Gao, S.: Composition of the continental crust. Treatise. Geochem. 3, 1-64, 2003.

Schellart, W.P.: Influence of the subducting plate velocity on the geometry of the slab and migration of the subduction hinge. Earth Planet. Sci. Lett. 231, 197-219, 2005.

Schellart, W.P.: Subduction zone trench migration: Slab driven or overriding-plate driven? Phys. Earth Planet. Inter. 170, 73-88, 2008.

Scott, E.M., and Allen, M.B., Macpherson, C.G., McCaffrey, K.J.W., Davidson, J.P., Saville, C., Ducea, M.N.: Andean surface uplift constrained by radiogenic isotopes of arc lavas. Nat. Commun. 9, doi: 10.1038/s41467-018-03173-4, 2018.

Shannon. R.D.: Revised effective ionic radii and systematic studies of interatomic distances in halides and chalcogenides. Acta Crystall. A-Crys. 32(5), 751-767, 1976.

Shaw, D.M.: Trace element fractionation during anatexis. Geochimica et Cosmochimica Acta 34, 237-243, 1970.

Söderlund, U., Patchett, P.J., Vervoort, J.D., and Isachsen, C.E.: The $176 \mathrm{Lu}$ decay constant determined by Lu-Hf and U-Pb isotope systematics of Precambrian mafic intrusions. Earth Planet. Sci. Lett. 219(3), 311-324, 2004.

Su, N., Zhu, G., Wu, X.D., Yin, H., Lu, Y.C., and Zhang, S.: Back-arc tectonic tempos: Records from Jurassic-Cretaceous basins in the eastern North China Craton, Gondwana Research, https://doi.org/10.1016/j.gr.2020.12.002, 2021.

Sun, S. S., and McDonough, W. F.: Chemical and isotopic systematics of oceanic basalts: implications for mantle composition and processes. Geol. Soc. Lond. Spec. Publ. 42, 313-345, 1989.

Tang. J., Xu. W. L., Wang. F., and Ge. W.C.: Subduction history of the Paleo-Pacific slab beneath Eurasian continent: Mesozoic-Paleogene magmatic records in Northeast Asia. Sci. China-Earth Sci. 61, 527-559, 2018.

Treuil, M., and Joron, J.L.: Utilisation des elements hygromagmatophiles pour la simplification de la modélisation quantitative des processusMagmatiques: exemples de l'Afar et de la dorsale médio-atlantique. Societa Italiana Mineralogia e Petrologia 31, 125-74, 1975.

Vervoort, J.D., and Blichert-Toft, J.: Evolution of the depleted mantle: Hf isotope evidence from juvenile rocks through time. Geochim. Cosmochim. Acta 63(3), 533-556, 1999.

600 Wan, Y.S., Song, B., Liu, D.Y., Wilde, S. A., Wu, J.S., Shi, Y.R., Yin, X.Y., and Zhou, H.Y.: SHRIMP U-Pb zircon geochronology of Palaeoproterozoic metasedimentary rocks in the North China Craton: Evidence for a major Late Palaeoproterozoic tectonothermal event. Precambrian Res. 149, 271, 2006.

Wang, K.X, Yu, C.D., Yan, J., Liu, X.D., Liu, W.H., and Pan, J.Y.: Petrogenesis of Early Silurian granitoids in the Longshoushan area and their implications for the extensional environment of the North Qilian Orogenic Belt, China. Lithos 342-343, 152-174, 2019.

Wang, N., Wu, C. L, Lei, M., and Chen, H.J.: Petrogenesis and tectonic implications of the Early Paleozoic granites in the western segment of the North Qilian orogenic belt, China. Lithos 312-313, 89-107, 2018. 
https://doi.org/10.5194/se-2021-129

Preprint. Discussion started: 17 November 2021

(c) Author(s) 2021. CC BY 4.0 License.

\section{(c) (1)}

Wang, X., Griffin, W. L., Chen, J., Huang, P.Y., and Li, X.: U and Th contents and Th/U ratios of zircon in felsic and mafic magmatic rocks: Improved zircon-melt distribution coefficients. Acta Geol. Sin.-Engl. Ed. 85, 164-174, 2011.

Wang, X., Griffin, W. L., O'Reilly, S. Y., and Li, W.X.: Three stages of zircon growth in magmatic rocks from the Pingtan Complex, eastern China. Acta Geol. Sin.-Engl. Ed. 81, 68-80, 2007.

Wang, X.L., Lv, X., Liu, Y.J., Zhao, Y.Y., Li, C., Wu, W.B., Wang, Y.P., and Li, H.Y.: LA-ICP-MS zircon U-Pb ages, geochemical characteristics of Late Triassic intrusives in Xiuyan area, eastern Liaoning and their geological significances. Geol. Rev. 65, 401-416, 2019 (in Chinese with English abstract).

615 Watson, E. B., and Harrison, T. M.: Zircon saturation revisited: temperature and composition effects in a variety of crustal magma types. Earth Planet. Sci. Lett. 64, 295-304, 1983.

Watson, E. B., and Harrison, T. M.: Zircon thermometer reveals minimum melting conditions on earliest Earth. Science 308, 841-844, 2005.

Wu, F. Y., Yang, J. H., and Liu, X. M.: Geochronological framework of the Mesozoic granitic magmatism in the Liaodong Peninsula, Northeast China. Geol. J. China Univ. 11, 305-317, 2005b (in Chinese with English abstract).

Wu, F.Y., Han, R.H., Yang, J.H., Wilde, S. A., Zhai, M.G., and Park, S. C.: Initial constraints on the timing of granitic magmatism in North Korea using U-Pb zircon geochronology. Chem. Geol. 238, 232-248, 2007.

Wu, F.Y., Lin, J.Q., Wilde, S. A., Zhang, X.O., and Yang, J.H.: Nature and significance of the Early Cretaceous giant igneous event in eastern China. Earth Planet. Sci. Lett. 233, 103-119, $2005 \mathrm{c}$.

Wu, F.Y., Yang, J.H., Wilde, S. A., and Zhang, X.O.: Geochronology, petrogenesis and tectonic implications of Jurassic granites in the Liaodong Peninsula, NE China. Chem. Geol. 221, 127-156, 2005a.

Xiao, B., Li, Q.G., Liu, S.W., Wang, Z.Q., Yang, P.T., Chen, J.L., and Xu, X.Y.: Highly fractionated Late Triassic I-type granites and related molybdenum mineralization in the Qinling orogenic belt: Geochemical and $\mathrm{U}-\mathrm{Pb}-\mathrm{Hf}$ and $\mathrm{Re}-\mathrm{Os}$ isotope constraints. Ore Geol. Rev. 56, 220-233, 2014.

630 Xu, J. F., R. Shinjo, M. J. Defant, Q. Wang, and R. P. Rapp.: Origin of Mesozoic adakitic intrusive rocks in the Ningzhen area of east China: partial melting of delaminated lower continental crust? Geology 30(12), 1111-1114, 2004.

Xue, J. X., Liu, Z. H., Liu, J. X., Dong, X. J., Feng, F., and Lian, G. H.: Geochemistry, Geochronology, Hf isotope and Tectonic Significance of the Late Jurassic Huangdi Pluton in Xiuyan, Liaodong Penins. Earth Science doi: 10.3799/dqkx.2020.008, 2020 (in Chinese with English abstract).

635 Yang, F.C., Song, Y.H., Hao, L.B., and Peng, C.: Late Jurassic SHRIMP U-Pb age and Hf isotopic characteristics of granite from the Sanjiazi Area in Liaodong and their geological significance. Acta Geol. Sin. 89, 1773-1782, 2015a (in Chinese with English abstract).

Yang, F.C., Song, Y.H., Yang, J.L., Shen, X., and Gu, Y.C.: SHRIMP U-Pb age and geochemical characteristics of granites in Wulong-Sidaogou Gold Deposit, East Liaoning. Geotectonica Et Metallogenia, 42, 940-954, 2018 (in Chinese with English abstract). 
https://doi.org/10.5194/se-2021-129

Preprint. Discussion started: 17 November 2021

(c) Author(s) 2021. CC BY 4.0 License.

(c) (i)

Yang, H., Zhang, H.F., Xiao, W.J., Luo, B.J., Gao, Z., Tao, L., Zhang, L.Q., and Guo, L.: Petrogenesis of Early Paleozoic high $\mathrm{Sr} / \mathrm{Y}$ intrusive rocks from the North Qilian orogen: Implication for diachronous continental collision. Lithosphere, 2020, 12, 53-73, 2019.

Yang, J. H., Wu, F. Y., Xie, L. W., and Liu, X. M.: Petrogenesis and tectonic implications of Kuangdonggou synites in the Liaodong Peninsula, east North China Craton: Constraints from in-suit zircon U-Pb ages and $\mathrm{Hf}$ isotopes. Acta Petrol. Sin. 23, 263-276, 2007 (in Chinese with English abstract).

Yang, J.H., Wu, F.Y., Lo, C.H., Chung, S.L., Zhang, Y,B., and Wilde, S.A.: Deformation age of Jurassic granites in the Dandong area, eastern China: Ar-40/Ar-39 geochronological constraints. Acta Petrol. Sin. 20(5), 1205-1214, 2004 (in Chinese with English abstract).

Yang, M. C., Chen, B., and Yan, C.: Petrological, geochronological, geochemical and Sr-Nd-Hf isotopic constraints on the petrogenesis of the Shuangcha Paleoproterozoic megaporphyritic granite in the southern Jilin Province: Tectonic implications. Acta Petrol. Sin. 31, 1573-1588, 2015b (in Chinese with English abstract).

Yang, M.C., Chen, B., and Yan, C.: Paleoproterozoic Gneissic Granites in the Liaoji Mobile Belt, North China Craton: Implications for Tectonic Setting. In: Zhai M., Zhao Y., Zhao T. (eds) Main Tectonic Events and Metallogeny of the North China Craton. Springer Geology. Springer, Singapore. https://doi.org/10.1007/978-981-10-1064-4_7, 2016

Yang, W., and Li, S.G.: Geochronology and geochemistry of the Mesozoic volcanic rocks in western Liaoning: Implications for lithospheric thinning of the North China Craton. Lithos 102, 88-117, 2008.

Zeng, R.Y., Lai, J.Q., Mao, X.C., Li, B., Ju, P.J., and Tao, S.L.: Geochemistry, zircon U-Pb dating and Hf isotopies composition of Paleozoic granitoids in Jinchuan, NW China: Constraints on their petrogenesis, source characteristics and tectonic implication. J. Asian Earth Sci. 121, 20-33, 2016.

Zeng, R.Y., Lai, J.Q., Mao, X.C., Li, B., Zhang, J.D., Bayless, R., and Yang, L.Z.: Paleoproterozoic Multiple Tectonothermal Events in the Longshoushan Area, Western North China Craton and Their Geological Implication: Evidence from Geochemistry, Zircon U-Pb Geochronology and Hf Isotopes. Minerals-Basel 8, 2018.

Zhai, M.G., Meng, Q.R., Liu, J.M., Hou, Q.L., Hu, S.B., Li, Z., Zhang, H.F., Liu, W., Shao, J.A., and Zhu, R.X.: Geological features of Mesozoic tectonic regime inversion in eastern North China and implication for geodynamics. Earth Science Frontiers 11, 285-298, 2004.

Zhan, Q. Y., Zhu, D. C., Wang, Q., Weinberg, R. F., Xie, J. C., Li, S. M., Zhang, L.L., and Zhao, Z. D.: Source and pressure effects in the genesis of the Late Triassic high Sr/Y granites from the Songpan-Ganzi Fold Belt, eastern Tibetan Plateau. Lithos 368-369, 105584, 2020.

Zhang S H, Zhao Y, Davis G A, Ye H, and Wu F.: Temporal and spatial variations of Mesozoic magmatism and deformation in the North China Craton: Implications for lithospheric thinning and decratonization. Earth-Sci Rev, 131, 49-87, 2014.

Zhang, B., Guo, F., Zhang, X. B., Wu, Y.M., Wang, G.Q., and Zhao, L.: Early Cretaceous subduction of Paleo-Pacific Ocean in the coastal region of SE China: Petrological and geochemical constraints from the mafic intrusions. Lithos 334-335, 8-24, 2019. 
https://doi.org/10.5194/se-2021-129

Preprint. Discussion started: 17 November 2021

(c) Author(s) 2021. CC BY 4.0 License.

(c) (i)

675 Zhang, B.L., Zhu, G., Jiang, D.Z., Li, C.C., and Chen, Y.: Evolution of the Yiwulvshan metamorphic core complex from distributed to localized deformation and its tectonic implications. Tectonics 31, TC4018. https://doi.org/10.1029/2012TC003104, 2012.

Zhang, Q., Qian, Q., Wang, E.Q., Wang, Y., Zhao, T.P., Hao, J., and Guo, G.J.: An East China plateau in mid-late Yanshanian period: implication from adakites. Chinese Journal of Geology 36 (2), 248-255, 2001 (In Chinese with English abstract).

Zhang, Q., Wang, Y., Liu, H., Wang, Y.: On the space-time distribution and geodynamic environments of adakites in china annex: controversies over differing opinions for adakites in china. Earth science frontiers, 2003 (In Chinese with English abstract).

Zhang, S., Zhu, G., Xiao, S.Y., Su, N., Liu, C., Wu, X.D., Yin, H., Li, Y.J., and Lu, Y.C.: Temporal variations in the dynamic evolution of an overriding plate: Evidence from the Wulong area in the eastern North China Craton, China. Geol. Soc. Am. Bull. https://doi.org/10.1130/B35465.1, 2020.

Zhao, K.D., Jiang, S.Y., Ling, H.F., and Palmer, M. R.: Reliability of LA-ICP-MS U-Pb dating of zircons with high U concentrations: A case study from the U-bearing Douzhashan Granite in South China. Chem. Geol. 389, 110-121, 2014.

Zheng J P, and Dai H K.: Subduction and retreating of the western Pacific plate resulted in lithospheric mantle replacement and coupled basinmountain respond in the North China Craton. Sci. China-Earth Sci. 61: 406-424, 2018.

Zheng, Y.F., Xu, Z.F., Zhao, Z.F., and Dai, L.Q.: Mesozoic mafic magmatism in North China: Implications for thinning and destruction of cratonic lithosphere. Sci. China-Earth Sci. 61, 353-385, 2018.

Zhu, R.X., and Xu, Y.G.: The subduction of the west Pacific plate and the destruction of the North China Craton. Sci. ChinaEarth Sci. 62, 1340-1350, 2019. 
https://doi.org/10.5194/se-2021-129

Preprint. Discussion started: 17 November 2021

(c) Author(s) 2021. CC BY 4.0 License.
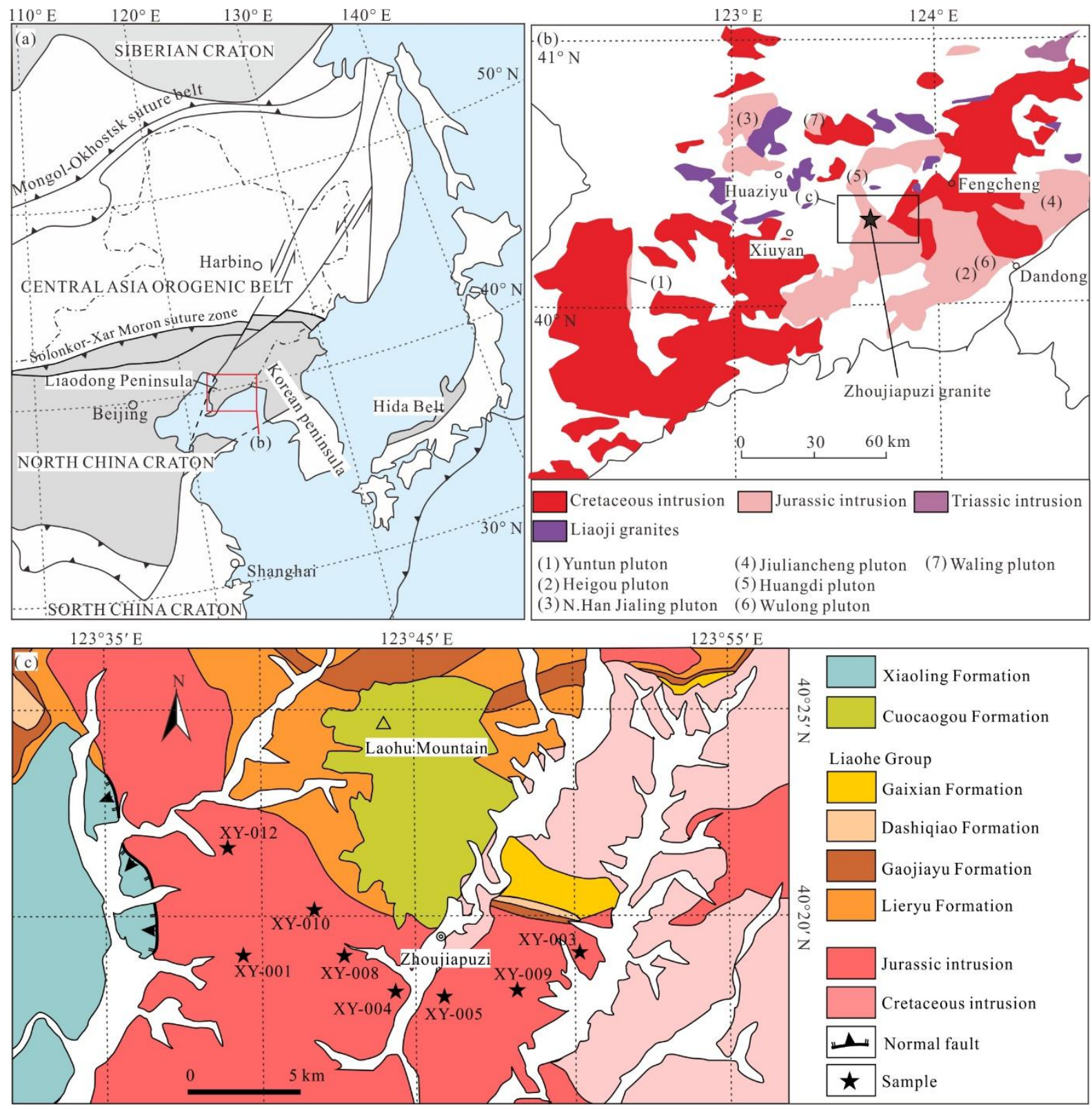

Figure 1: (a) Simplified geological map of Northeast China (Modified from Li et al., 2016); (b) distribution of Mesozoic intrusions in the Liaodong Peninsula (Modified from Wu et al., 2005a); (c) geological map of the Zhoujiapuzi granite. 
https://doi.org/10.5194/se-2021-129

Preprint. Discussion started: 17 November 2021

(c) Author(s) 2021. CC BY 4.0 License.

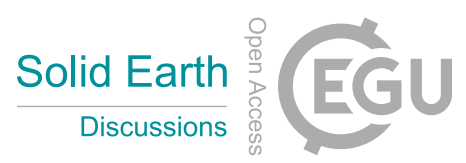
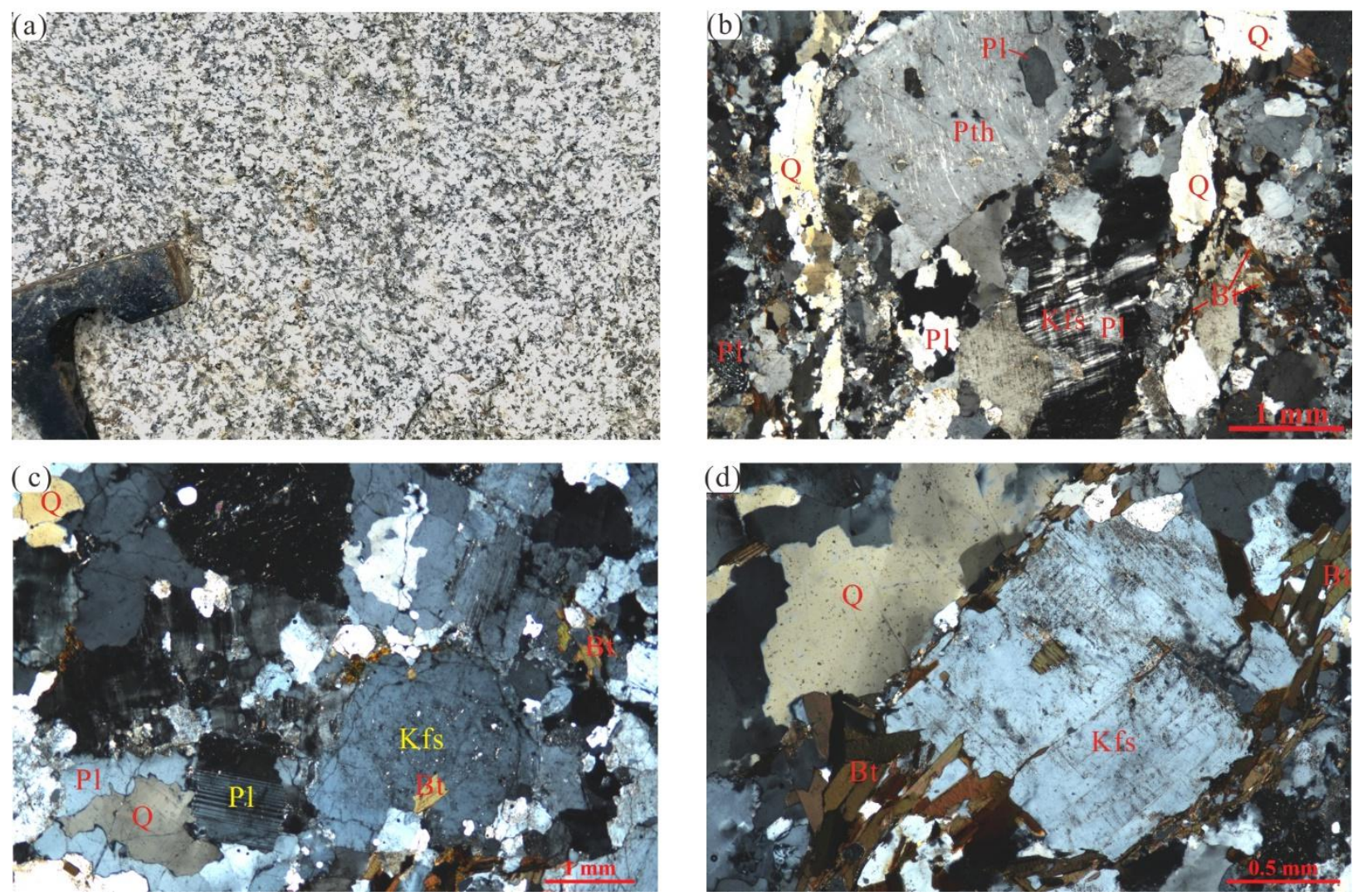

Figure 2: Outcrop photograph (a) and corresponding micrographs (b, c, d- perpendicular polarized light). Q quartz; Kfs feldspar;

Pl plagioclase; Pth perthite; Bt biotite 
https://doi.org/10.5194/se-2021-129

Preprint. Discussion started: 17 November 2021

(c) Author(s) 2021. CC BY 4.0 License.

(c) (i)
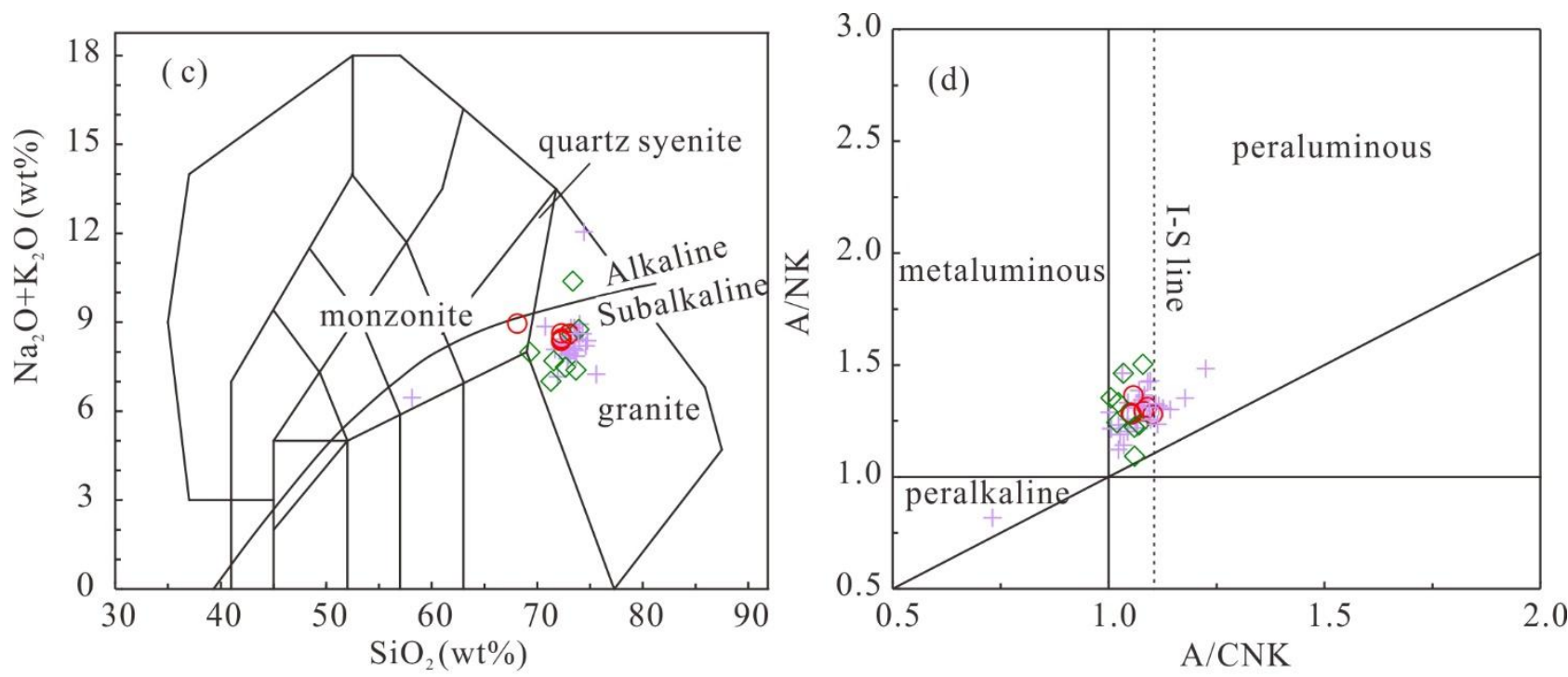

Zhoujiapuzi granite (this study)

+ Other middle-late Jurassic granitoids in Liaodong Peninsula

(Wu et al., 2005a; Yang et al., 2015b, 2018; Xue et al., 2020)

$\diamond$ Muniuhe granitic pluton (Yang et al., 2016; Wang et al., 2020)

Figure 3: (a) TAS diagram (after Frost et al., 2001); (b)A/CNK-A/NK diagram (after Maniar and Piccoli, 1989)
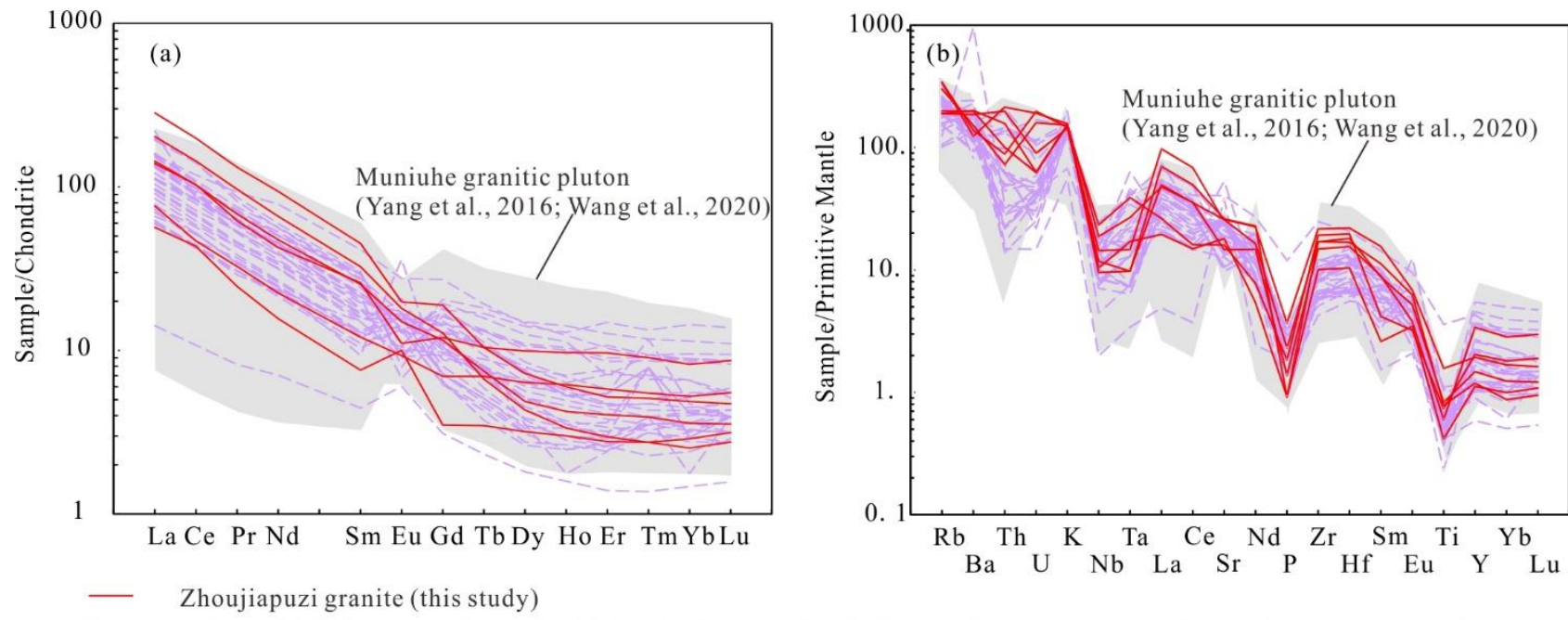

Other middle-late Jurassic granitoids in Liaodong Peninsula (Wu et al., 2005a; Yang et al., 2015b, 2018; Xue et al., 2020)

Figure 4: Chondrite-normalized REE patterns and primitive mantle-normalized trace element patterns of the Zhoujiapuzi granite (chondrite and primitive mantle values are from Sun and McDonough, 1989). 
https://doi.org/10.5194/se-2021-129

Preprint. Discussion started: 17 November 2021

(c) Author(s) 2021. CC BY 4.0 License.

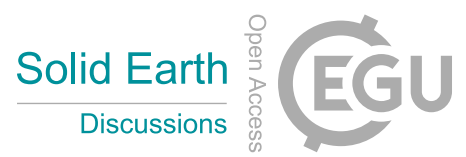

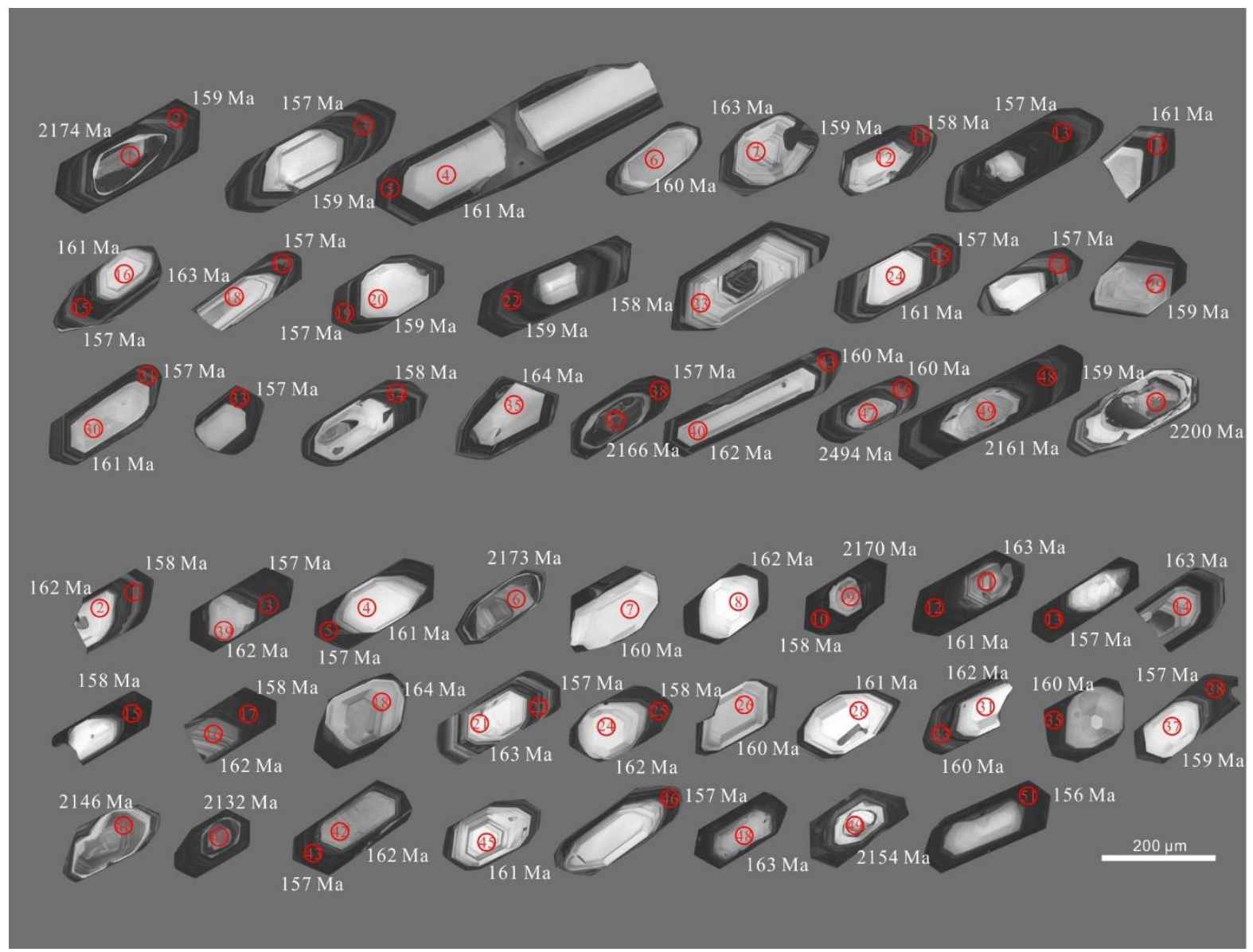

Figure 5: CL images of zircons. Circles denote $\mathrm{U}-\mathrm{Pb}$ analysis spot. Numbers in the circles are the spot numbers. Numbers near the 710 analytical spots are the $\mathrm{U}-\mathrm{Pb}$ ages (Ma). 
https://doi.org/10.5194/se-2021-129

Preprint. Discussion started: 17 November 2021

(c) Author(s) 2021. CC BY 4.0 License.
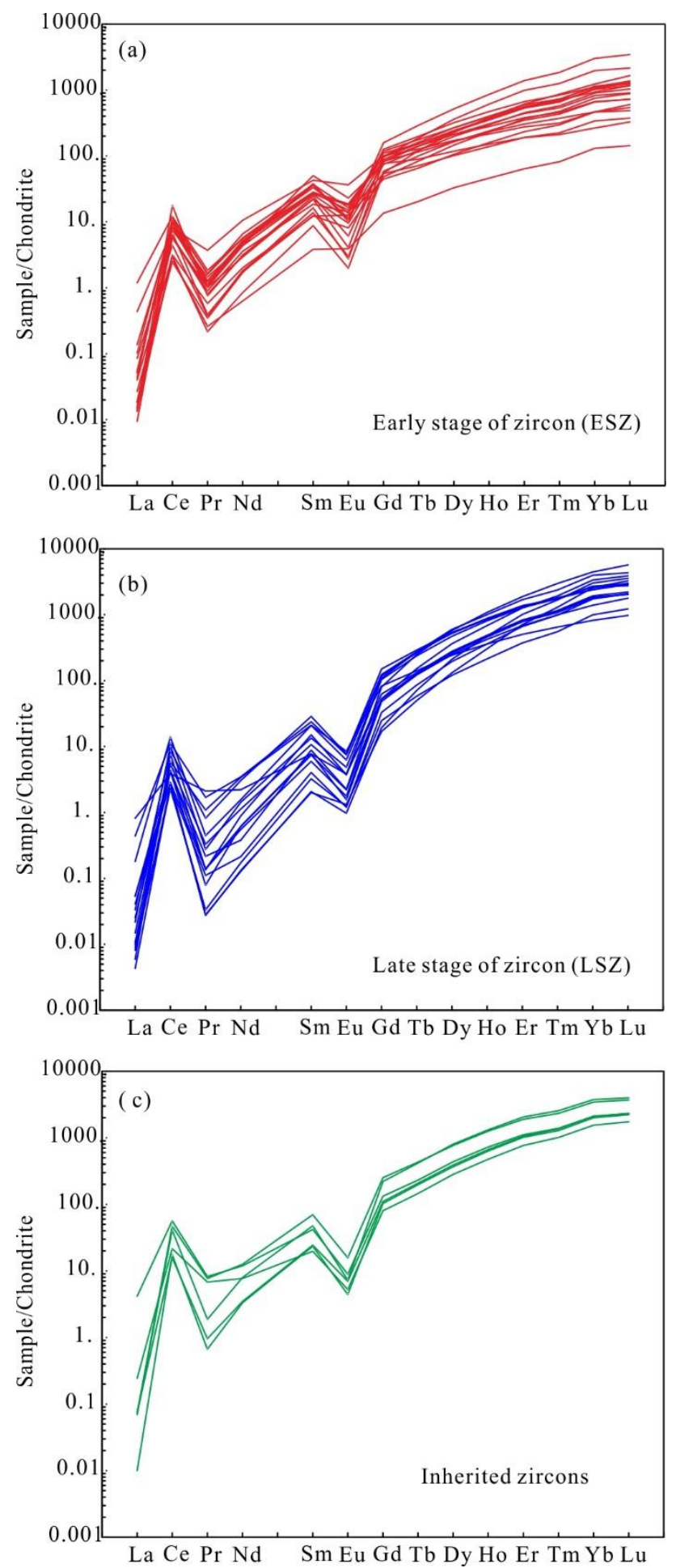

Figure 6: Chondrite-normalized REE patterns of zircon (chondrite values are from Sun and McDonough, 1989). 
https://doi.org/10.5194/se-2021-129

Preprint. Discussion started: 17 November 2021

(c) Author(s) 2021. CC BY 4.0 License.
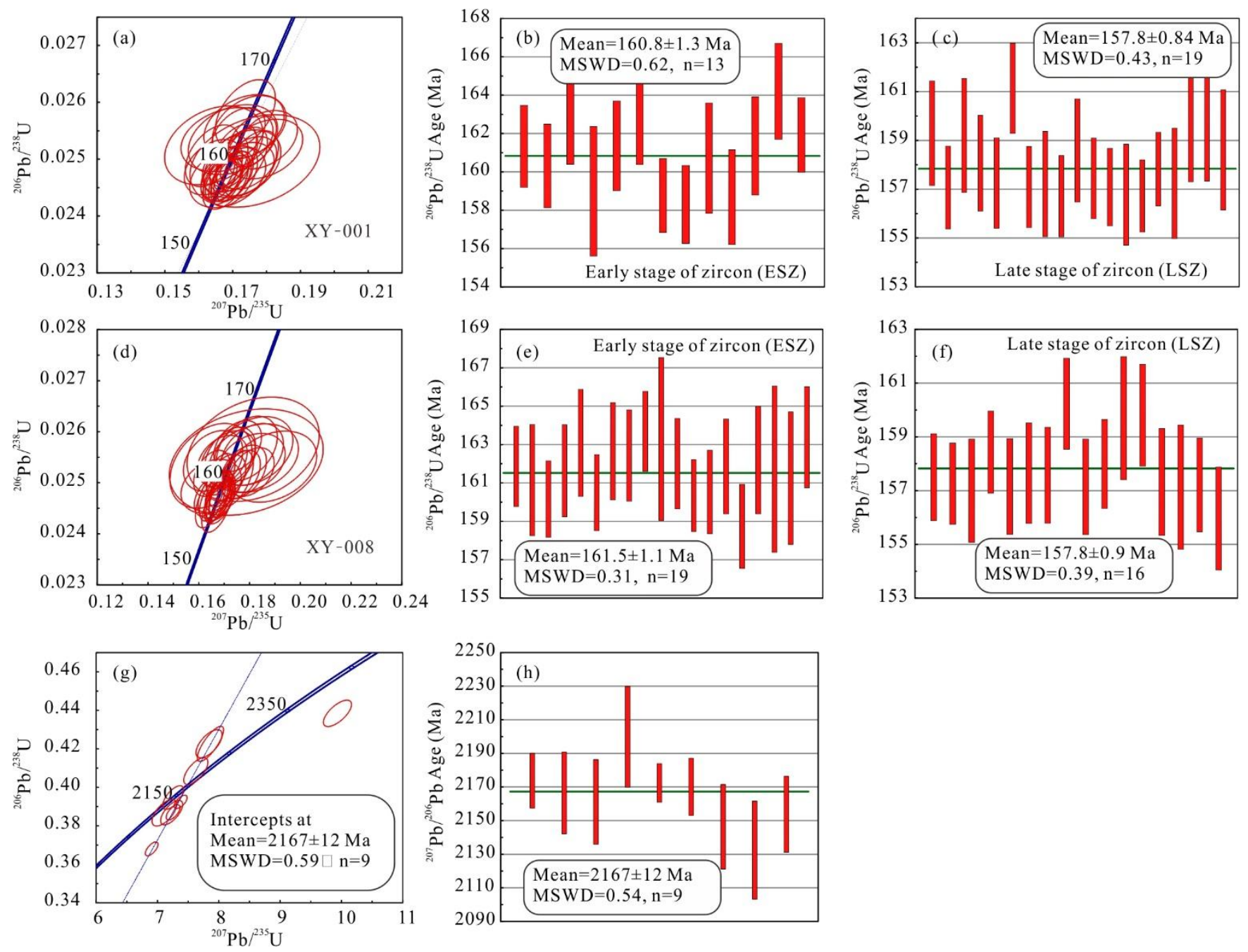

Figure 7: Concordia diagrams for zircon LA-ICP-MS U-Pb analyses. 
https://doi.org/10.5194/se-2021-129

Preprint. Discussion started: 17 November 2021

(c) Author(s) 2021. CC BY 4.0 License.
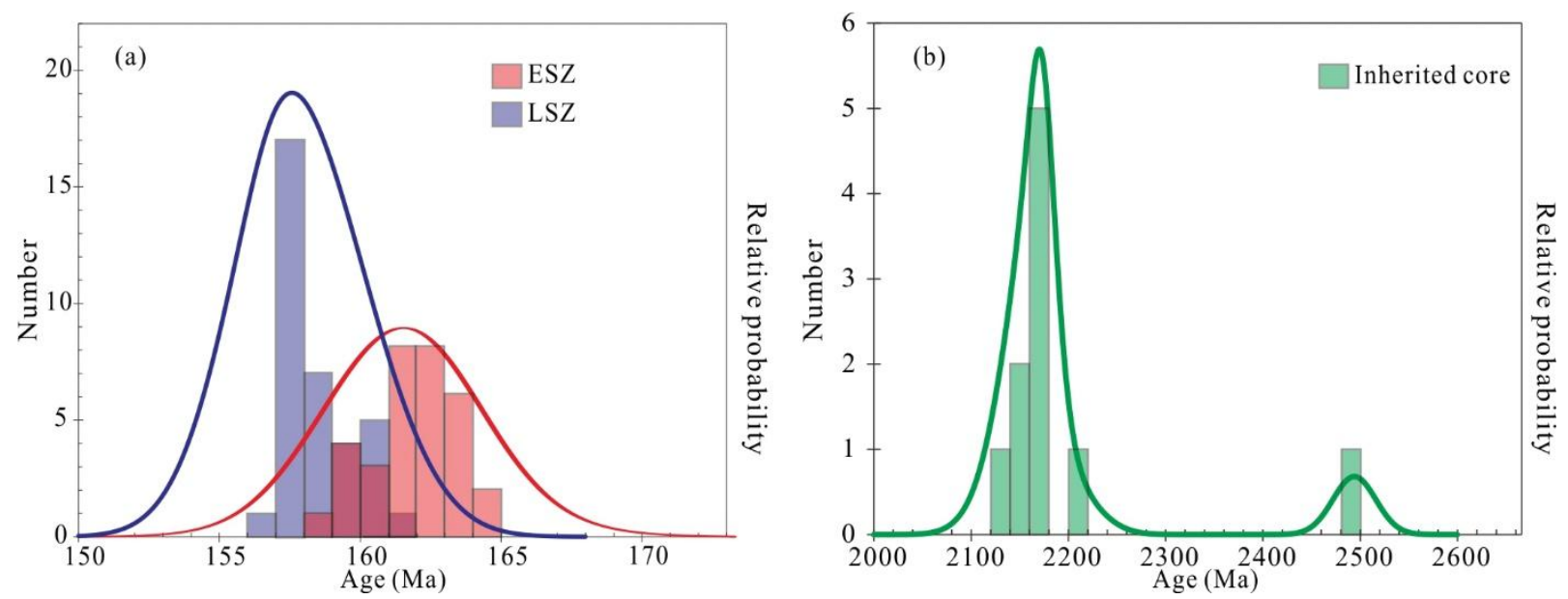

Figure 8: Zircon relative probability diagram

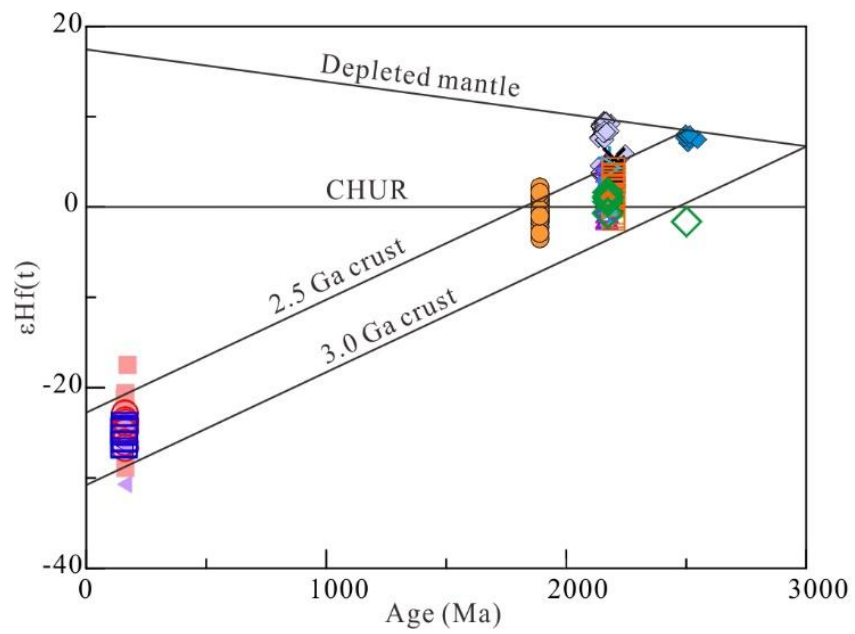

- Meta-mafic rocks (Meng et al., 2014)

$\diamond$ Inherited igneous zircons (Meng et al., 2014)

Liaoji granites:

$\triangleright$ Granite from the Heigou area (Yang et al., 2020)

$\square$ Muniuhe granite (Yang et al., 2016)

$\times$ Simenzi granite (Yang et al., 2016)

+ Hupiyu granite (Yang et al., 2016)

$\triangle$ Hadabei granite (Yang et al., 2016)

- Shuangcha granitic pluton (Yang et al., 2015a)

Granite from the Sanjiazi area (Yang et al., 2015b)

4 Huangdi granitic pluton (Xue et al., 2020)

- Early stage of zircon (ESZ, this study)

$\square$ Late stage of zircon (LSZ, this study)

$\diamond$ Inherited zircon (This study)

Figure 9: Zircon $\mathrm{EHf}(\mathrm{t})$-age (Ma) diagram for samples in this study and published data for the region. 
https://doi.org/10.5194/se-2021-129

Preprint. Discussion started: 17 November 2021

(c) Author(s) 2021. CC BY 4.0 License.
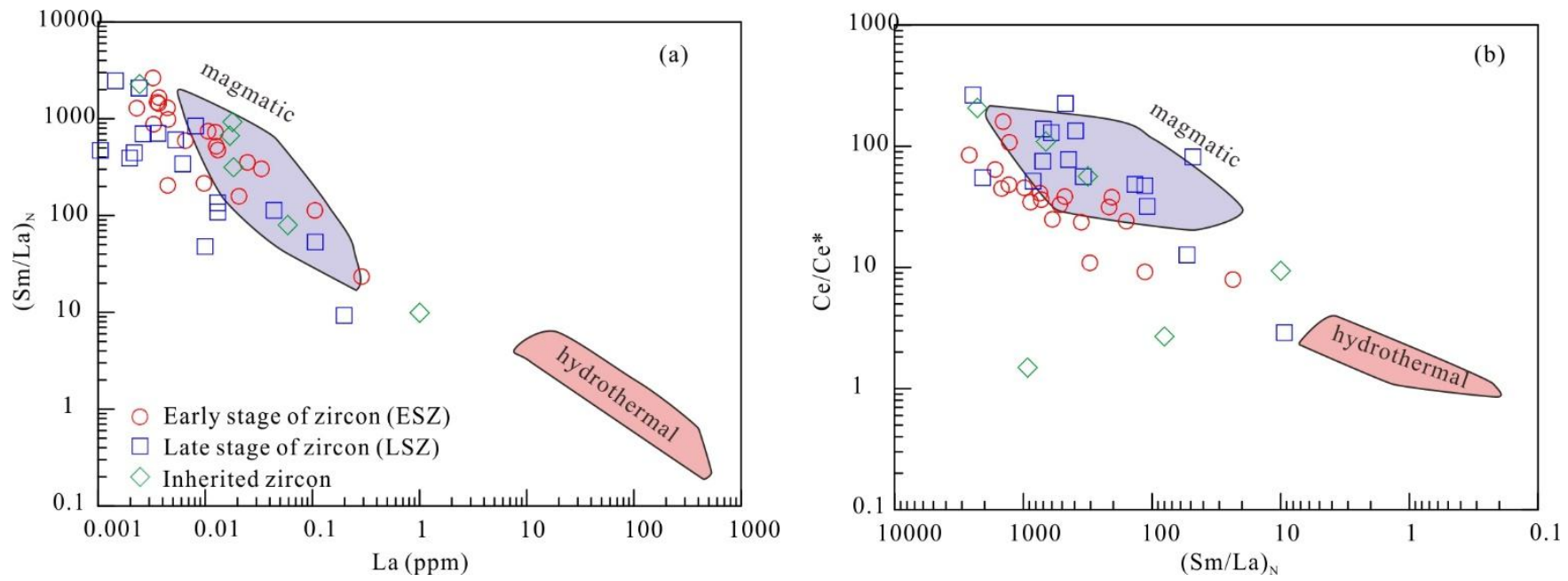

Fig. 10: Discrimination plots for magmatic and hydrothermal zircon (Hoskin, 2005).
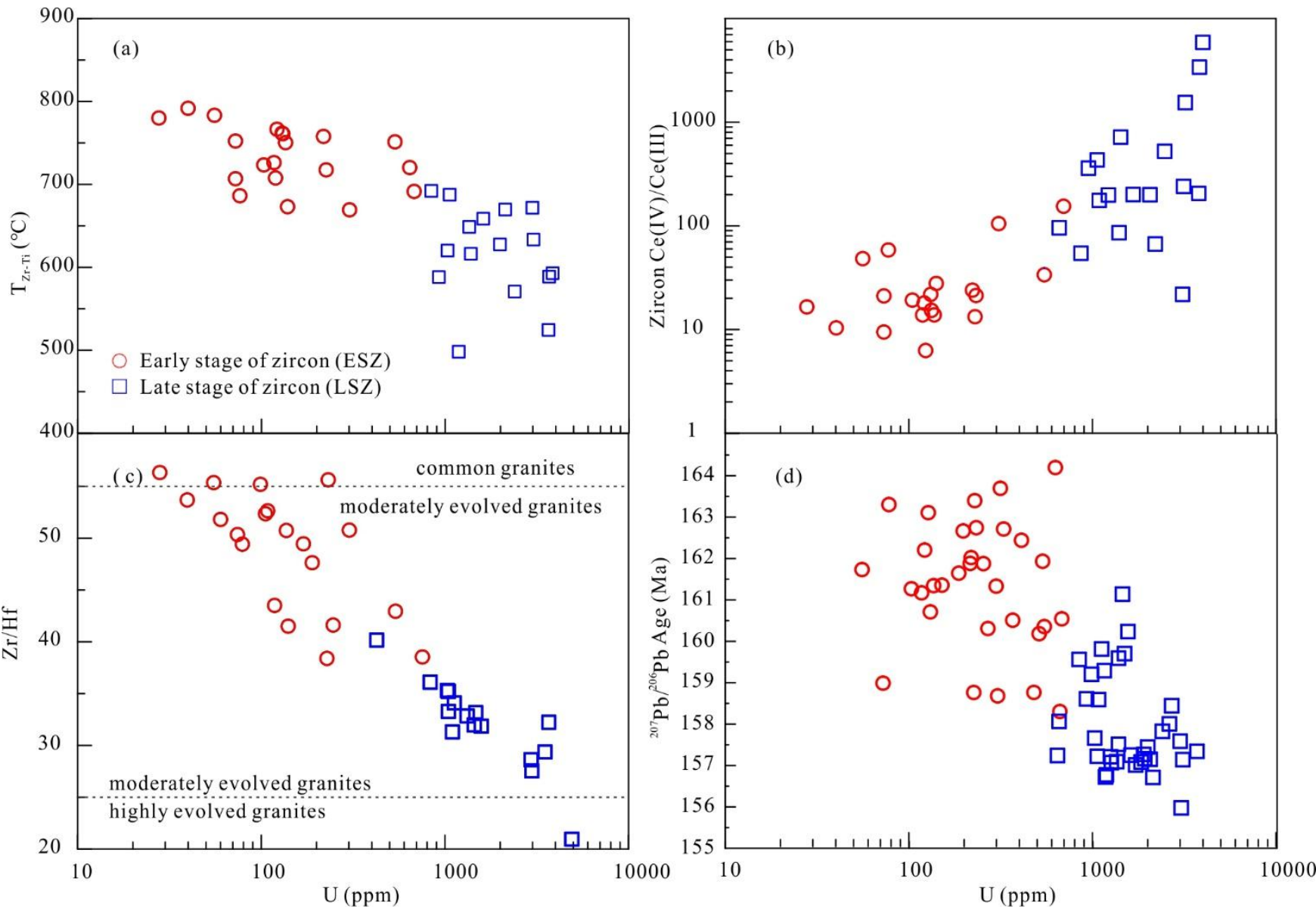
https://doi.org/10.5194/se-2021-129

Preprint. Discussion started: 17 November 2021

(c) Author(s) 2021. CC BY 4.0 License.

Figure 11: (a) zircon T ( $\left.{ }^{\circ} \mathrm{C}\right)-\mathrm{U}$ (ppm) diagram; (b) zircon Ce(IV)/Ce (III)-U (ppm) diagram; (c) zircon Zr/Hf-U (ppm) diagram (dividing line from Breiter et al., 2014); (d) age (Ma)-U (ppm) diagram.
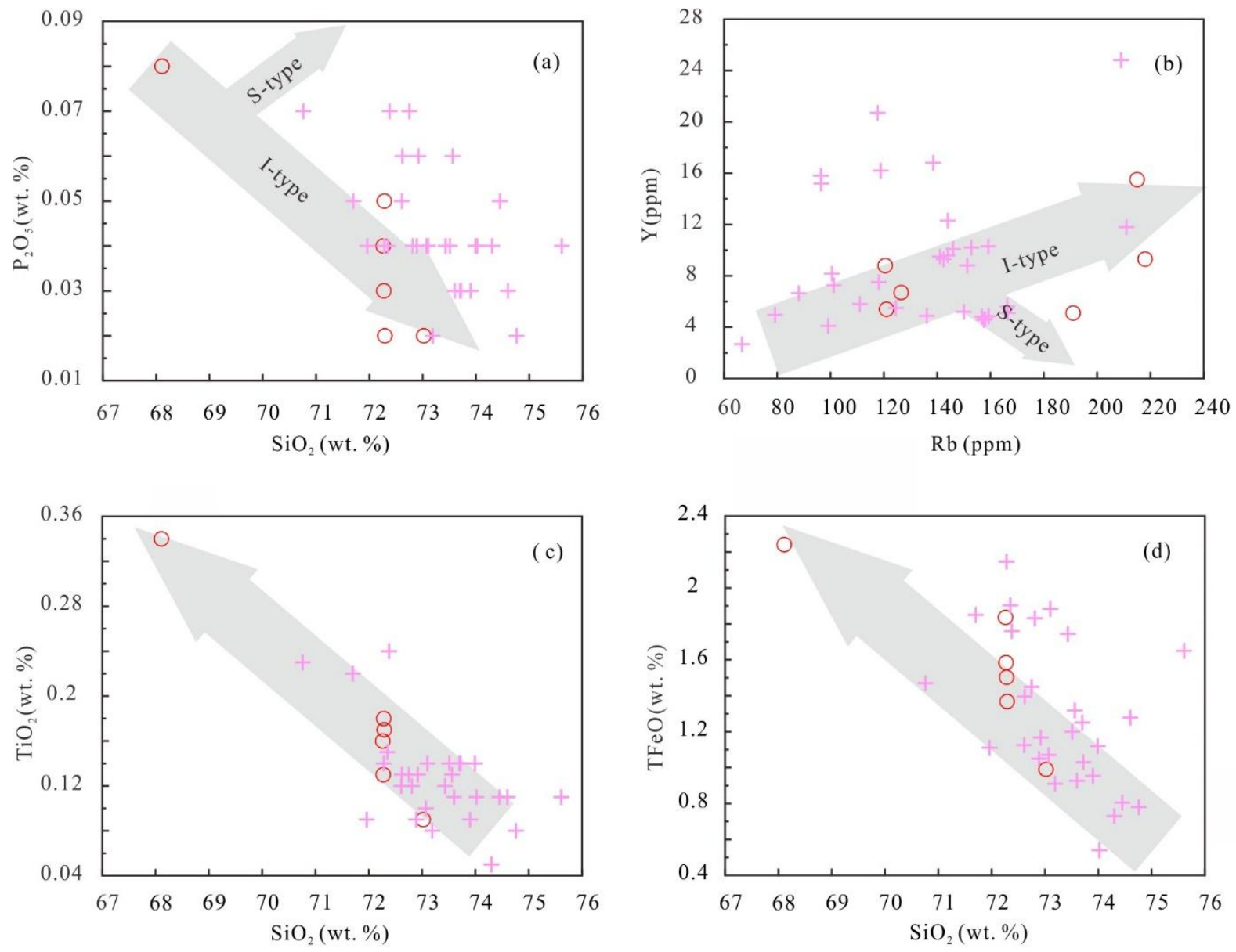

O Zhoujiapuzi granite (this study)

+ Other middle-late Jurassic granitoids in Liaodong Peninsula (Wu et al., 2005a; Yang et al., 2015b, 2018; Xue et al., 2020)

Figure 12: Chemical variation diagrams for the Zhoujiapuzi granite. 
https://doi.org/10.5194/se-2021-129

Preprint. Discussion started: 17 November 2021

(c) Author(s) 2021. CC BY 4.0 License.
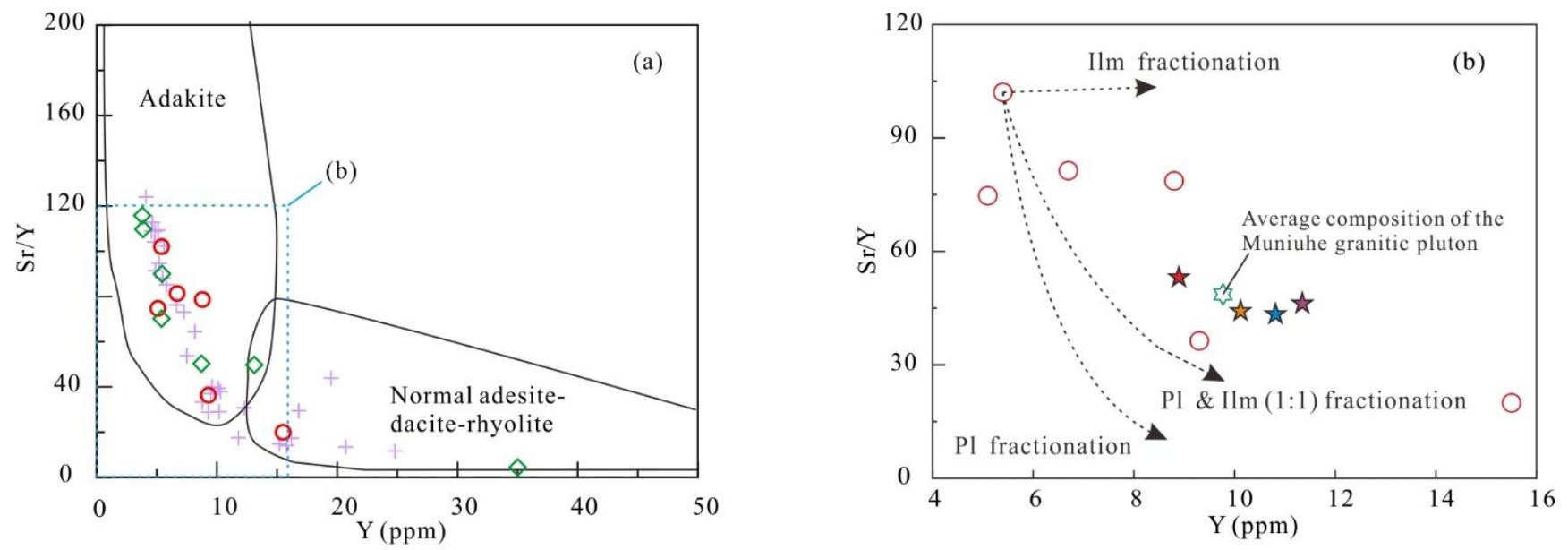

O Zhoujiapuzi granite (this study)

Other middle-late Jurassic granitoids in Liaodong Peninsula (Wu et al., 2005a; Yang et al., 2015b, 2018; Xue et al., 2020)

$\diamond$ Muniuhe granitic pluton (Yang et al., 2016; Wang et al., 2020)

$\sum_{3}$ Average composition of the Muniuhe granitic pluton (Yang et al., 2016; Wang et al., 2020)

$\star$ Simulated source $(\mathrm{Sr}=473 \mathrm{ppm} ; \mathrm{Y}=8.9 \mathrm{ppm})$ based on the residual mineralogy of $\mathrm{Amp}(\mathrm{F}=85.5 \%)$

Simulated source $(\mathrm{Sr}=447 \mathrm{ppm} ; \mathrm{Y}=10.1 \mathrm{ppm})$ based on the residual mineralogy of $\mathrm{Amp}: \mathrm{Ilm}=98.9: 1.2(\mathrm{~F}=80.8 \%)$

Simulated source $(\mathrm{Sr}=469 \mathrm{ppm} ; \mathrm{Y}=10.8 \mathrm{ppm})$ based on the residual mineralogy of Amp: $\mathrm{Pl}: \mathrm{Ilm}=92.7: 6.9: 0.5(\mathrm{~F}=78.1 \%)$

Simulated source $(\mathrm{Sr}=524 \mathrm{ppm} ; \mathrm{Y}=11.3 \mathrm{ppm})$ based on the residual mineralogy of Amp: $\mathrm{Pl}: \mathrm{Ilm}=82.4: 18.3(\mathrm{~F}=72.2 \%)$

Figure 13: Plots of (a) Sr/Y vs. Y, (b) $\mathrm{La}_{N} / \mathrm{Yb}_{N}$ vs. Y $\mathbf{b}_{\mathrm{N}}$ (after Defant and Drummond, 1990) 
https://doi.org/10.5194/se-2021-129

Preprint. Discussion started: 17 November 2021

(c) Author(s) 2021. CC BY 4.0 License.
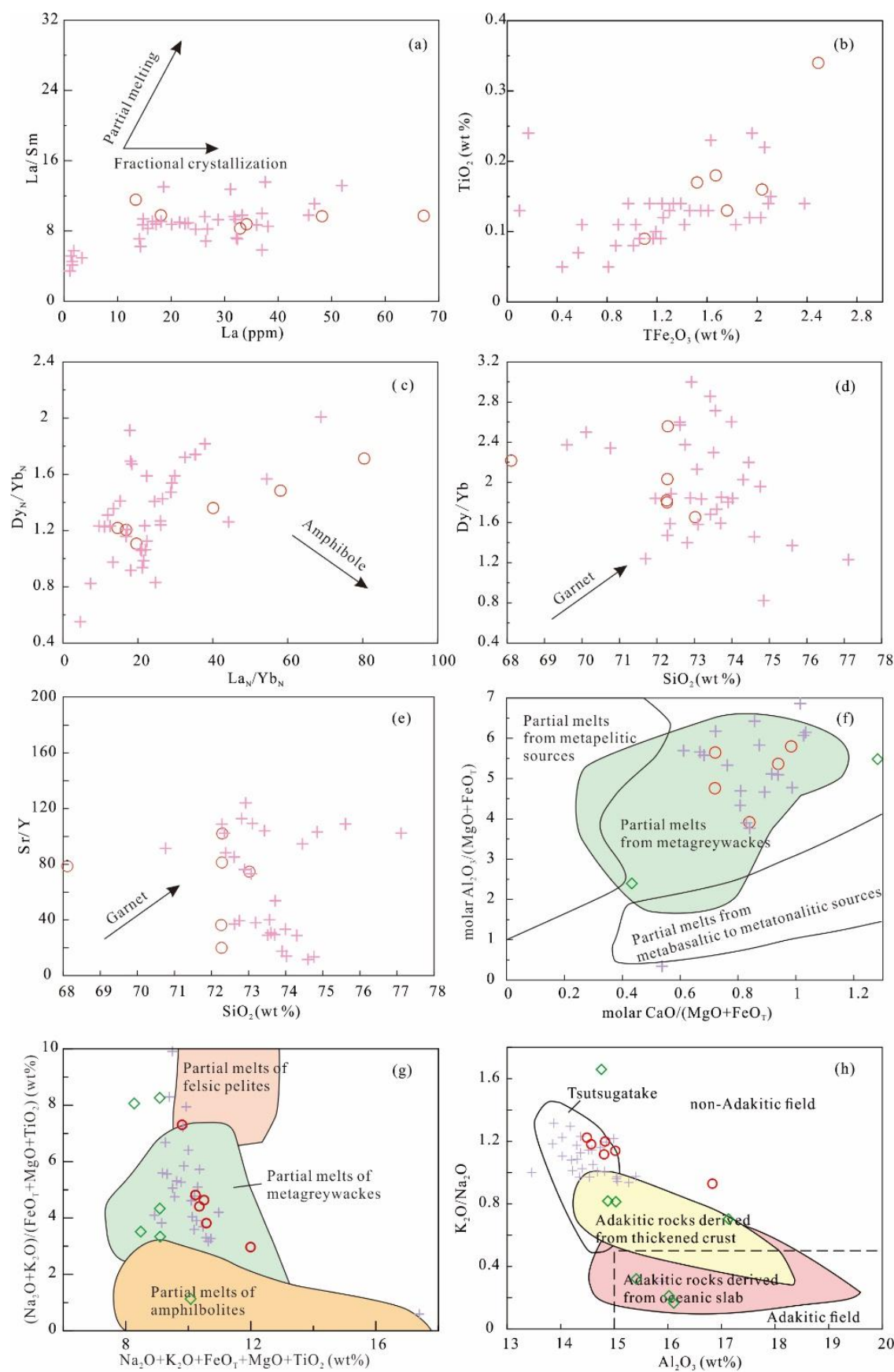

$\circ$ Zhoujiapuzi granite (this study)

Other middle-late Jurassic granitoids in Liaodong Peninsula (Wu et al., 2005a; Yang et al., 2015b, 2018; Xue et al., 2020)

Figure 14: Plots of (a)Zr/Hf vs. Zr, (b) $\mathrm{TiO}_{2}$ vs. $\mathrm{TFe}_{2} \mathrm{O}_{3}$, ( c) $\mathrm{Dy}_{\mathrm{N}} / \mathrm{Yb}_{\mathrm{N}}$ vs. $\mathrm{La}_{\mathrm{N}} / \mathrm{Yb}_{\mathrm{N}}$; (d) Dy/Yb vs. $\mathrm{SiO}_{2}$; (e) $\mathrm{Sr} / \mathrm{Y}$ vs. $\mathrm{SiO}$; (f) molar $\mathrm{Al}_{2} \mathrm{O}_{3} /\left(\mathrm{MgO}_{+} \mathrm{FeO}_{\mathrm{T}}\right)$ vs. molar $\mathrm{CaO} /\left(\mathrm{MgO}_{+} \mathrm{FeO}_{\mathrm{T}}\right) ;(\mathrm{g})\left(\mathrm{Na}_{2} \mathrm{O}+\mathrm{K}_{2} \mathrm{O}\right) /\left(\mathrm{FeO}_{\mathrm{T}}+\mathrm{MgO}+\mathrm{TiO}_{2}\right) \quad$ vs. $\mathrm{Na}_{2} \mathrm{O}+\mathrm{K}_{2} \mathrm{O}+\mathrm{FeO}_{\mathrm{T}}+\mathrm{MgO}+\mathrm{TiO}_{2} ;(\mathrm{h})$ $\mathrm{K}_{2} \mathrm{O} / \mathrm{Na}_{2} \mathrm{O}$ vs. $\mathrm{Al}_{2} \mathrm{O}_{3}$ diagrams(a after Treuil and Joron, 1975; f after Altherr et al., 2000; g after Patiño Douce, 1999; $h$ after Kamei et al., 2009) 
https://doi.org/10.5194/se-2021-129

Preprint. Discussion started: 17 November 2021

(c) Author(s) 2021. CC BY 4.0 License.
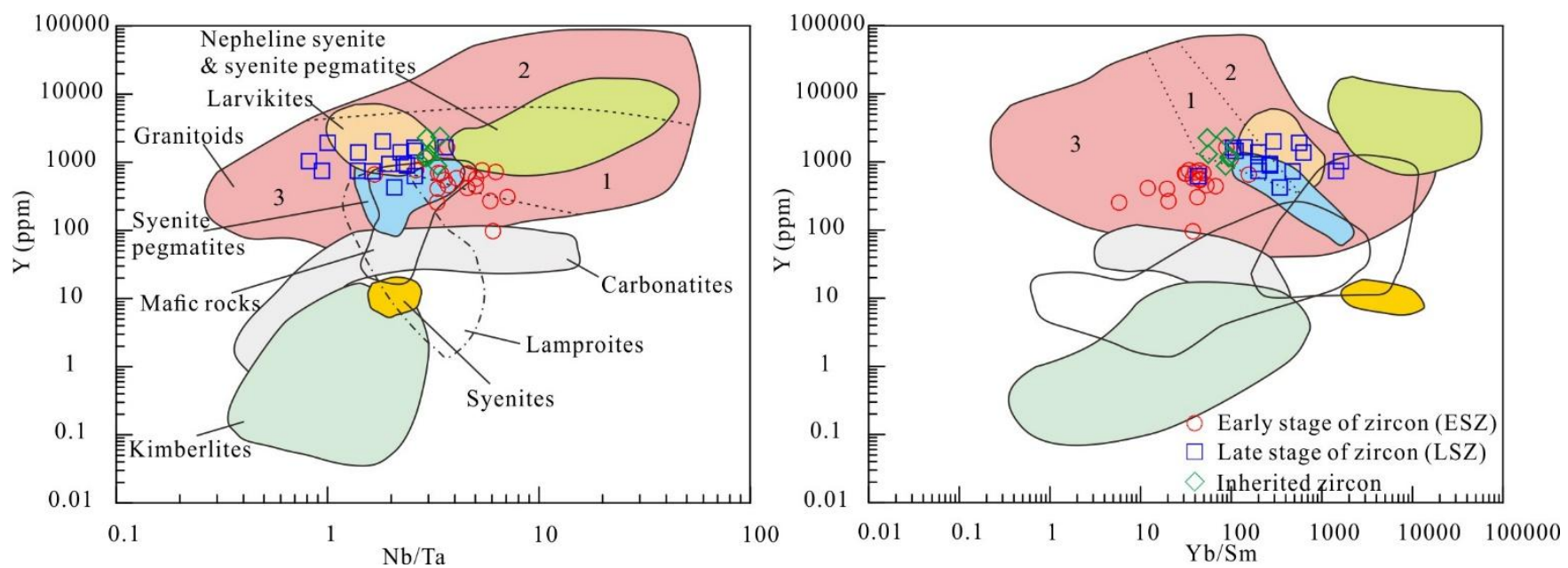

Figure 15: The fields of zircon compositions used as discriminants for different rock types (after Belousova et al., 2002).

'Granitoids' include: 1 aplites and leucogranites; 2 granites; 3 granodiorites and tonalities 